\title{
Mersin Toroslar'da Çandır Kalesi
}

\section{Çandir Castle at the Taurus Mountains of Mersin}

\author{
Halil Sözlü* $\odot$, Lale Yılmaz ${ }^{* *}$
}

\section{Öz}

Mersin ili, tarih boyunca bölgenin savunma ve egemenliğinde önem taşıyan yapılar olarak tanımlanabilecek çok sayıda kale yapısının inşa edildiği bir bölgede yer almaktadır. Özellikle Ortaçağ döneminde etkin olarak yerleşme ve savunma bakımından kullanılan kale yapıları, kuzeyden güneye limanlara ulaşan ticaret yollarının güvenliğini sağlamaktaydı. Makalede coğrafi konumu ve yapısal özellikleri bakımından özgün bir nitelik taşıyan Çandır Kalesi ele alınmıştır. Kalenin yalnızca bir savunma yapısı olarak değil, geniş bir alanı kaplayan yapılardan oluşan küçük bir yerleşim birimi olarak kurulduğu anlaşılmaktadır. Çalışmada Kilikya Bölgesi'nde Ortaçağ'da Bizans döneminde Ermeni baronluğuna ait olarak tanımlanan Çandır Kalesi üzerine yapılmış tarihsel çalışmalar incelenmiş, kale alanında günümüze ulaşan yapı kalıntıları belirlenmiştir. Günümüzde Çandır Kalesi’nde görülebilen doğal ve insan eliyle gerçekleşen yıkım, kale kompleksinin yapısal özelliklerinin yeniden tanımlanmasını gerekli kılmıştır.

\section{Anahtar Kelimeler}

Mersin, Ortaçağ, Bizans, Paperon, Kale

\begin{abstract}
Mersin is located in a region where many fortress structures have been built, which can be defined as structures that are important in the defense and sovereignty of the region throughout history. Especially in the Middle Ages, the castle structures, which were used effectively in terms of settlement and defense, ensured the security of the trade routes reaching the ports from north to south. It is understood that the fortress structures were established at strategic points on the main transportation and trade routes. In the research, the Çandır Castle, which has a unique character in terms of its geographical location, has been the subject of the study. It is understood that the castle was built not only as a defensive structure but as a small settlement consisting of structures covering a large area. In this article, historical studies on the Çandır Castle, which was defined as belonging to the Armenian baron in the Cilician Region during the Middle Ages, were examined and the remains of the building surviving in the castle area were identified. The natural and man-made destruction that can be seen in Çandır Castle today requires the redefinition of the structural features of the castle complex.
\end{abstract}

\section{Keywords}

Mersin, Middle Age, Byzantine, Paperon, Castle

* Sorumlu Yazar: Halil Sözlü (Dr. Öğr. Üyesi), Mersin Üniversitesi, Fen-Edebiyat Fakültesi, Sanat Tarihi Bölümü, Mersin, Türkiye. E-posta: halilsozlu@mersin.edu.tr ORCID: 0000-0002-3100-486X

** Lale Yılmaz (Dr. Öğr. Üyesi), Mersin Üniversitesi, Turizm Fakültesi, Turizm Rehberliği Bölümü, Mersin, Türkiye. E-posta: laleyilmaz@mersin.edu.tr ORCID: 0000-0002-3767-6499

Attf: Sozlu, Halil ve Yilmaz, Lale. “Mersin Toroslar'da Çandır Kalesi.” Art-Sanat, 13 (2020): 361-385. https://doi.org/10.26650/artsanat.2020.13.0015 


\section{Extended Summary}

The Kilikya plain has a large area, surrounded by the Taurus Mountains and Amanos Mountains to the south, Iskenderun to the south, the north and east, and the Silifke coast to the west. A limited number of mountain passes are provided in this area.

The geographical features of the region, which are seen as advantageous in the sea and land transportation, can turn into a disadvantage to the north. On the other hand, transportation to the Cilician Gates in the Taurus Mountains was possible. These routes were observed in the transportation between the Konya Plain and the ports located on the Mediterranean coast. Castle structures were built on the main and intermediate roads connecting the road to the sea. Mersin was defended by the fortress structures required by the unique geographical structure of the Taurus Mountains, which were formed by elevations and steep mountain passages. There are 37 fortresses and watchtowers in total in Mersin. Today, the village / neighborhood called Çandır is located $7 \mathrm{~km}$ east of the Ayvagediği plateau in the Toroslar district of Mersin. Çandır Castle, located at a point where trade and transportation routes meet, is situated at a height of $1450 \mathrm{~m}, 40 \mathrm{~km}$ north of Mersin, in an area dominating the area. It is located at a point where trade and transportation routes meet, situated at a height of $1450 \mathrm{~m}$, $40 \mathrm{~km}$ north of Mersin, in an area dominating the area. It is understood that the location of the fortress is at the intersection of the three historical regions, Cappadocia, Isauria and Cilicia. The fact that the fortress was built on a high hill is an indication of its dominance over these three regions. At the end of the 11th century, the castle passed into the hands of the Armenian dynasties and it is defined as the fortress of Hetums in the sources during the Middle Ages. It can be seen that the castle consists of only the inner castle. The castle is surrounded by valleys and is located on the northeastern façade. The ladder exit consists of two stages. In the first section, there are steps leading up to the north. At the end of this place with a half-round arched door opening to the other stairs. The stairs then continue to the south. Gate B is reached after the stairs. The door is half-round arched, and is made of smooth cut stone. Gate $\mathrm{B}$ is arranged in the form of a guard room and has a loophole window on the east side. The inner fortress is reached through section B through several steps. The two-stage and zigzag entrance section is only seen here in the castles of the Cilicia region. The inner castle floor is rocky and covered with hard vegetation. The architectural structures are mostly concentrated in the northwest of the inner fortress. To the southeast of the castle, a few remains of small buildings have survived. Since the castle was built on the main rock in a high position, it was not surrounded by the valleys, so there was no need to build a fortification on every facade. The walls were built mostly on the north and west sides. In the castle built on the natural formation and the main rock, the architectural elements are positioned accordingly. The use of natural defensive formations is one of the general features of the castles of Cilicia. 
Inner castle structures like the church, housing ruins, cisterns, courtyard and sarcophage can be seen. The remnants of the church are the remains of an annexed structure with a rounded apse, pastophorion cells, a section of the south walls and a cross on a stone block placed on the northern side. The identified remains probably indicate a religious structure with three naves which is not considered too small for the castle. The facade of the church was covered with a flat wall. Due to the partial demolition of the façade stones, only the central window can be seen. The D structure is west of the church and has survived to the north, south and east wall. It is understood from the remnants that it has a rectangular plan in the east-west direction. This structure, which cannot be understood for what purpose it was built, is probably related to the $\mathrm{E}$ complex in the west. Structure E is planned as a two-storey housing. Both in terms of the plan and the presence of the elements of ornamentation, this place is of particular importance in the castle. It is divided into four sections and has a two-storey layout. It is also located in the most sheltered place of the castle. The E1 section has a rectangular plan in the east-west direction and the whole of the northern wall and roof are destroyed. There are four openings with pointed arches to the E2 section to the south. The E3 section is rectangular in the east and west direction and has two floors, such as $\mathrm{E} 1$ and $\mathrm{E} 2$. The $\mathrm{E} 4$ section is a rectangular and small scale section near the square to the north of E3. North of the community of buildings, there is a vaulted F site with a slightly lower level than the inner fortress level. It is thought that this place could be a cistern based on the plasters inside the room. The $\mathrm{G}$ structure is in the west of the $\mathrm{H}$ courtyard to the north of the E3 section and has a rectangular plan in the north-south direction. The courtyard $\mathrm{H}$ is a second interior in the inner fortress by surrounding the E structures, church, structure G, structure D, structure F and structure I from the east and south. The $\mathrm{K}$ structure is a rectangular cistern to the east of the $\mathrm{H}$ courtyard and in the east-west direction. The functions and types of the $\mathrm{L}$ and $\mathrm{M}$ structures could not be determined exactly. Since the walls of the $\mathrm{N}$ and $\mathrm{O}$ structures are plastered, it is highly like to be a cistern. With the study of Çandır Castle, it was determined that the castles in the Cilicia region had significant and common features in terms of structure and function. 


\section{Giriş}

Kilikya ovas1, güneyde İskenderun, batı, kuzey ve doğuda Toroslar ve Amanos Dağları ile çevrelenmiştir. Batıda Silifke yer almaktadır. Ulaşım açısından güç sayılabilecek bu coğrafi alanda sınırlı sayıda dağ geçitleriyle ulaşım sağlanmaktadır. Kilikya bölgesi genel bir tanımla, Anadolu'da Akdeniz Bölgesi'nin doğusunda Alanya'nın doğusundan başlayan ve Suriye kıyılarına kadar uzanan kıyı şeridiyle kuzeyde Karaman'a ulaşan ve Çukurova'yı da kaplayan alandır. Strabon, Kilikya bölgesinin sınırlarının batıda Korakesion (Alanya) ile başladığını kaydetmiştir: "Kilikya'da ilk olarak, çok dik bir kayaya oturmuş bir kale olan Korakesion'a gelinir. (...) Tauros'un dışında kalan Kilikia'ya gelince, onun bir parçası Trakheia ve diğeri Pedias olarak adlandırılır." Kilikya bölgesi, Anadolu' da Akdeniz'in doğusunda, denizsel ve karasal alana sahip, stratejik bir konumdadır.

Dağlık ve ovalık olarak iki bölüme ayrılan Kilikya, Trakheia kıyısının dar oluşu, düzlük toprağının az görülmesiyle karakterize edilmiştir. Bölgenin deniz ve kara ulaşımında avantaj olan coğrafi özellikleri kuzeyde dezavantaja dönüşebilmektedir. Buna karşın Toros Dağları'nda yer alan Kilikya Kapıları (Gülek Boğazı, Gülek Geçidi) ile Tarsus limanına doğrudan ulaşılmaktaydı. Gülek Geçidi, tarih boyunca kuzeyde Adana-Pozantı yönünden Tarsus'a erişen yolun güney doğrultusunu oluşturmuştur. Bölgede yer alan diğer dağ geçitleri, Sertavul, Belen ve Amanos ile ulaşım sağlanmaktaydı. Genel olarak Konya Ovası'yla Akdeniz kıyısındaki limanlar arasındaki ulaşımda bu güzergâhlar izlenmekteydi. Karayolunu deniz yoluna bağlayan ana ve ara yollar üzerinde kale yapıları inşa edilmiştir. Bölgedeki kalelerin genellikle Bizans devrinde var olan ve özellikle 1080-1375 yılları arasında Ermeni egemenliği döneminde mimari bakımdan güçlendirilen yapılar olduğu görüşü mevcuttur. ${ }^{2} \mathrm{Bu}$ yapılar, Doğu Kilikya yolunda belirli aralıklarla inşa edildiği anlaşılan uzun ve zorlu birçok güzergâhın güvenliğini ve konrolünü sağlama amacıyla inşa edilmiştir. Kilikya bölgesi ve çevresindeki önemli güzergâhlar Konstantinopolis'e, Maraş ve Kayseri gibi merkezlere ulaşan yollarla oluşmuştur ${ }^{3}$ (G. 1).

Strabon, Antik Anadolu Coğrafyası: Geographika (İstanbul: Arkeoloji ve Sanat Yayınları, 2005), 253.

2 G.R. Youngs, "Three Cilician Castles," Anatolian Studies 15 (1965), 113-134.

3 Kristian Molin, Unknown Crusader Castles (New York: Hambledon Continuum, 2001), 152. 

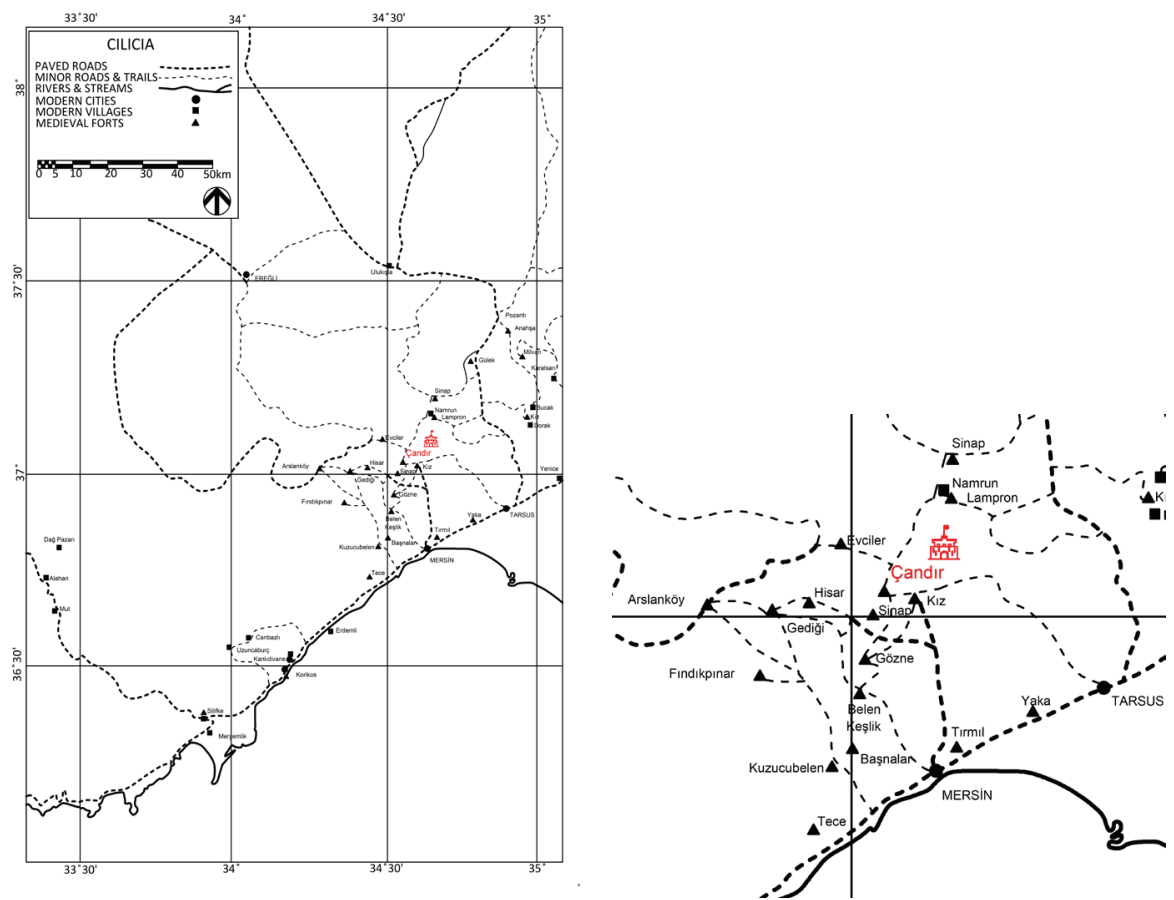

G. 1. Dağl1k Kilikya kaleleri güzergâh1, Robert W. Edwards, The Fortifications of Armenian Cilicia, 1987, XIX (uygulama: S. Eren, 2019).

Mersin, Toroslarda yükseltilerin ve sarp dağ geçitlerinin oluşturduğu bir coğrafi yapıya sahiptir. Kalelerin kurulduğu doğal yükseltiler, yolların güvenliğine ve kontrolüne yönelik olarak kullanılmıştır. Mersin'de envanteri yapılmış 37 adet kale ve gözetleme kulesi bulunmaktadır. ${ }^{4}$ Tarih boyunca nüfusun ve yerleşme sayısının artması, buna bağlı olarak ticaret etkinliğinin gelişmesi, Toros Dağları'nda hâlen kullanılmakta olan Gülek Boğazı, Sertavul Geçidi, Belen Geçidi gibi geçitlerin varlığıyla birlikte ulaşımın aksamadan sürdürüldüğü güzergâhın kalıcılaşmasını sağlamıştır.

Roma, Bizans, Arap, Haçlı, Memluk, Karamanoğulları ve 14. yüzyılın ikinci yarısında Osmanlı devrinde Kilikya ve Isauria bölgelerinde çok sayıda ve büyüklükte kale ve gözetleme kulesi inşa edilmiştir. Ortaçağ' daki siyasi durum ve stratejik konumları nedeniyle bu kaleler, Bizans devrinde bölgede bir bakıma uç beyliği olarak hâkimiyet kurmalarına izin verilen Ermeni hanedanlarının yönetimine bırakılmışıtır. Kaleler tipik Ermeni dağ kaleleri olarak tanımlanmıştır. Özellikle 11. yüzyılda Konstantinopolis tarafından Kilikya bölgesinin kontrolü zorlaşmıştır. Bu nedenle, 10. yüzyıldan itibaren bölgeye yerleşen Ermeni toplulukları yarı bağımsız krallıklar kurmuşlardır. ${ }^{5}$

4 “Kaleler, Hisarlar ve Tabyalar,” Mersin Kültür Turizm, erişim 17.05.2019. www.mersinkulturturizm.gov.tr/ TR-73469/kaleler--hisarlar-vetabyalar.html.

5 Charles A. Frazee, "The Christian Church in Cilician Armenia: Its Relations with Rome and Constantinople to 1198," Church History, (1976), 168; Molin, Unknown Crusader Castles, 146. 


\section{Çandır Kalesi’nin Konumu}

Günümüzde Çandır olarak adlandırılan köy/mahalle, Mersin'in Toroslar ilçesinde Ayvagediği yaylasının $7 \mathrm{~km}$ doğusundadır. Ticaret ve ulaşım bakımından önemli güzergahların birleştiği bir noktada yer alan Çandır Kalesi, Mersin'in 40 km kuzeyinde 1450 m yükseklikte, alana hâkim bir konuma sahiptir. Kale, batıdaki Gülek Boğazı Gülek Kalesi - Tarsus limanının aksine, ara yollar üzerinde kontrolü bulunan üç farklı yolun kesiştiği bir bölge üzerinde kurulmuştur. Edwards, kalenin inşa edildiği iki ana yolu şöyle tanımlamıştır: “Kuzeybatı yolu, günümüzdeki Ereğli'den (Konya) çıkarak Evciler'den geçen dar geçitlerden güneydoğuya kıvrılarak gider ve Lampron'dan gelen ikinci bir yol ile tek bir güney rotası oluşturmak için birleşir. Çandır'ın güneyinde denize doğru uzanan yol, diğer üç kale tarafindan korunur: Sinap, Gözne, Belenkeşlik." Ü đ̧ kale, Çandır Kalesi'ne bağlantılı güzergâhın korunması ve savunulması için kurulmuş askeri sistemin ve dolayısıyla bölgede yer alan bir yönetim alanının varlığına işaret etmektedir. Çandır Kalesi’nin de bölgedeki diğer kalelerde olduğu gibi başlangıçta bir Bizans savunma yapısı olarak kurulmuş olması, daha sonra Ermeni hanedanları tarafından yönetilmiş olması muhtemeldir.

\section{Tarihçe}

Kalede en erken tarihli araştırma Gottwald tarafından gerçekleştirilmiştir. Kalenin adı, Paperon, batı Ermenicesi'nde Baberon, Babaron, Baberu şeklinde telaffuz edilir.?

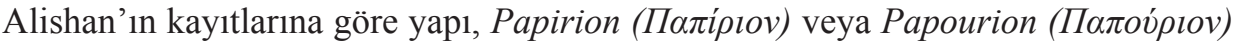
adlı bir Bizans kalesidir. Bizans devrinde Batı Kilikya’nın resmi yöneticileri olan Ermeni kralları, Bizans yönetiminin vasalları olarak kabul edilmekteydi ve Tarsus merkezli değil, Lampron ve Çandır kalelerinden yönetimi sağlamaktaydılar. ${ }^{8}$ Çandır'daki kale yapısının tarihsel geçmişinin Ermeni toplulukların yerleşmesinden önceye dayanması olasıdır. Helenistik dönemde Kilikya'daki Kyinda kalesinin varlığından hareketle Durukan, bölgede Kynda-Kundi eşitlemesi doğru bir tespit olarak kabul edildiğinde bu yerleşimin Gözne veya Çandır'da lokalize edildiğini öne sürmüştür. Ayrıca Gözne ve Çandır kaleleri, Asurların iki önemli kalesi olan Illubru (Lampron, Namrun) ve Ankhiale'ye egemen bir konumdadır. Çandır Kalesi'nin bulunduğu yerden 17 km kuzeyde yer alan Illubru (Namrun) Kalesi görülebilmektedir. Illubru (Namrun), Çandır ve Ankhiale yerleşimleri kuzey-güney hattında bulunmaktadır. ${ }^{9}$

6 Robert W. Edwards, The Fortifications of Armenian Cilicia (Washington: Dumbarton Oaks, 1987), 102.

7 J. Gottwald, "Die Kirche und das Schloss Paperon in Kilikisch-Armenien," Byzantinische Zeitscrift (1936), 87.

8 Léonce M. Alishan, Sissouan, ou L'Armeno-Cilicie, (Publié Sous Les Auspices De Son Ex, Noubar Pacha, Venise-S.Lazare, 1899), 72; Robert W. Edwards, "The Role of Military Architecture in Medieval Cilicia: The Triumph of a Non-UrbanStrategy," Armenian Cilicia, ed. R. Hovannasian, S. Payaslian, (California: Mazda 2008), 169.

9 Murat Durukan, Mersin'den Tarsus'a Kilikia Klyllarındaki Kayıp Kentler (İstanbul: Arkeoloji ve Sanat Yayınları, 2015), 67. 
Günümüzde Namrun'dan güneye giden iki güzergâhtan biri, batıya doğru kıvrılarak Çandır'a ulaşmaktadır. Diğer güzergâh ise Tarsus'tan Pozantı'ya ve Kapadokya'ya giden anayolla birleşmektedir. Namrun yöresi ve buradaki Lampron Kalesi de Çandır Kalesi ile birlikte Kilikya Kapıları'nın (Cilicia Pylai) güvenliğinin sağlanmasında önemli bir yapıyd1. ${ }^{10}$ Stilit Joshua’ya göre Paperon (Çandır) kalesi, İmparator Zeno tarafından hazineyi ve acil durumlar için gereken malzemeleri koruyan ve gözeten arkadaşı Illus'a emanet edilmiştir. ${ }^{11} 479$ yılında Verina'nın genç damadı Prens Marcinius, kaleye sürgün edilmiştir. Beş y1l sonra Illus geri çekilmiş ve idam edilmiştir. ${ }^{12}$ Zeno, Isauria kökenli bir imparator olmasının yanında mezhepsel anlamda bölgede imar faaliyetlerinde bulunmuştur. Bu bakımdan bölgede önemli bir yere sahip ve Erken Bizans dönemine ait 5. yüzyıl yapısı olan Alahan Manastırı'nın inşasına I. Leo döneminde başlandığ1 ve İmparator Zeno tarafından tamamlandığg öne sürülmektedir. ${ }^{13}$ Alahan Manastırı'nda olduğu gibi Dağpazarı, Meryemlik ve Korykos kiliseleri de İmparator Zeno dönemine tarihlendirilmektedir. ${ }^{14}$

Hetum hanedanının 12. yüzyılda bölgede egemenlik kuran Rupenoğulları'nın yerine geçtiği kaydedilmiştir. Hetum, Franklarla ve Moğollarla anlaşma yoluna gitmiştir. ${ }^{15}$

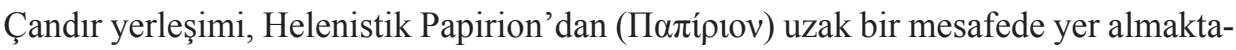
dır. Ancak kalenin konumu üç tarihsel bölgenin -Kapadokya, Isauria ve Kilikya'nınkesiştiği noktadadır. Kalenin yüksek bir tepe üzerinde kurulmuş olması bu üç bölgeye de egemenliğinin göstergesidir. Paperon'un Ermeniler tarafından ilk işgali konusunda, Lampronlu Nerses'in Skevra Manastırı'ndan Samuel hakkındaki 1190 civarında yazdığı tarihsel metinde şu bilgilere rastlanmaktadır:

“İmparator I. Aleksios, Ermeni Prensi Apllarip'i Vaspurakan'daki mevkiinden, Tarsus ve Misis'in yönetimini üstlenmek üzere Kilikya eyaletine gönderdi. Apllarip, Toros dağları eteklerindeki ve Tarsus'un dağlık kesimlerindeki iki saldırılamaz kale olan biri Lampron, diğeri Paperon'da bulundu. Her iki kale de çiftlik arazileri ve köylerle çevriliydi. Apllarip, hazine olarak Paperon'u aldı; kendisi ve ailesinin inzivası için büyük bir kilise inşa etti. Lampron'u Ermenistan'dan gelişinde ona yoldaşlık eden, güvendiği ve sevdiği prens Oşin'e verdi. Apllarip, öldüğünde Paperon'a gömüldü.”'16

10 Mersin: Örenyerleri, Kaleleri, Müzeleri, haz. Filiz Kerem (İstanbul: Ekin Yayıncılık, 2009), 96. Lampron Kalesi ile ilgili ayrıntılı bilgi için bkz. F.C.R. Robinson, P.C. Hughes, "Lampron: Castle of Armenian Cilicia," Anatolian Studies 19 (1969), 183-207.

11 Alishan, Sissouan, ou L'Armeno-Cilicie, 72.

12 Edwards, The Fortifications of Armenian Cilicia, 103.

13 Michael Gough, "The Emperor Zeno and Some Cilician Churches," Anatolian Studies 22 (1972), 201, 210.

14 Cyrill Mango, "Isaurian Builders," Polychronion, ed. P. Wirt (Heidelberg: Festschrift F. Dolger, 1966), 358365'den aktaran Gough, "The Emperor Zeno and Some Cilician Churches," 199.

15 Mehlika Aktok Kaşgarlı, Kilikya Tâbi Ermeni Baronluğu Tarihi (Ankara: Kök, 1990), 8-9.

16 Gottwald, "Die Kirche und das Schloss Paperon in Kilikisch-Armenien," 88. 
Kale, 11. yüzyılın sonlarında Ermeni Hanedanı Hetumidlerin eline geçmiştir. $\mathrm{Bu}$ nedenle Ortaçağ boyunca kaynaklarda tarihsel Hetumların kalesi olarak tanımlanmıştır. Kalenin maliklerinden Baron Smbat, 1151/1152'de Misis surlarının önünde Bizans ordusunun yanında, rakibi Rubenid Baron Toros'a karşı savaşırken ölmüştür. Smbat'ın oğlu Bakuran ise daha sonra 1169 civarında, Mleh'e zorla el konulması sırasında kızkardeşi Rita ve onun iki oğlu Ruben ve Levon'a sığınmıştır. Bakuran'ın, I. Levon'un taç giydiği 1198/1199 yılında, Paperon'un yöneticisi olarak ileri bir yaşa kadar yaşadığı ileri sürülmektedir. ${ }^{17}$ Daha sonra yerleşme, kardeşi Vasak'ın hakimiyetine, daha sonra ikinci oğlu Konstantin'e, sonunda Konstantin'in oğlu kale muhafızı Smbat'a geçmiştir. 1245 yılında Paperon'a, Selçuklu Sultanı II. Keyhüsrev ve müttefiki Lampronlu Konstantin tarafından bir akın gerçekleştirilmiştir. I. Hetum'a karşı Tarsus'a ilerleyişi sırasında yöreyi ateşe veren Kral II. Hetum'un kardeşi Toros, 1296'dan itibaren kalenin hâkimi olarak kabul edilir. Kale, suikastle öldürülen hükümdar Korykoslu Oşin'in döneminde hanedan yönetimine geçmiştir. Bölgede 13. yüzyılın sonlarında Memlûklerin ardından Karamanoğulları egemen olmuştur. Gottwald, 1347-1348 yıllarında Karamanoğulları'nın kaleyi ele geçirmesinden sonra Sultan Bayezid tarafindan fethedildiğini de belirtmiştir. ${ }^{18}$

\section{Mimari Özellikler}

Günümüzde Kaleye stabilize bir yolla ulaş1lır. Kale, İç Anadolu'dan Akdeniz'e bağlanan ara yol üzerinde inşa edilmiş olduğundan stratejik bir önem kazanmıştır. Ereğli'den başlayan bu güzergâh, Evciler Kalesi'nden geçtikten sonra Çandır, Sinap, Gözne ve Belenkeşlik Kaleleri üzerinden Mersin'e, Çukurova ve tüm güney bölgelere uzanmaktadır.

Etrafi vadilerle çevrili kaleye kuzeydoğu cephede yer alan yüz yirmi iki basamaklı merdivenle çıkılmaktadır (G. 2). ${ }^{19}$ Merdivenlerden önce A kapısı gelmektedir ancak bu kapıya çıkışı sağlayan bir merdiven bulunmaz. Olasılıkla taşınabilir ahşap bir merdivenle A kapısına çıkış sağlanmaktaydı. Merdivenli çıkış iki aşamadan oluşmaktadır. İlk bölümde kuzey yöne uzanan merdiven basamakları vardır. Bu bölümün sonunda yarım yuvarlak kemerli bir kapı açıklığıyla diğer merdivenli bölümün ardından merdivenler güneye doğru devam etmektedir. Üzeri kapal1, koridor şeklindeki bir geçitten sonra basamaklar devam eder. Merdiven basamakları dar yerlerde iki, geniş yerlerde üç veya dört düzgün kesme taştan yapılmıştır. Merdivenin yanına çağımıza ait demir bir korkuluk eklenmiştir.

17 Edwards, The Fortifications of Armenian Cilicia, 103.

18 Gottwald, "Die Kirche und das Schloss Paperon in Kilikisch-Armenien," 91.

19 Makalede, Robert W. Edwards’ın 1987 tarihli plan çizimlerinden yaralanılmış, Sultan Eren tarafından görsel netlik amacıyla çizimlerde yeniden uygulama yapılmıştır. Mimari çizim yapılırken plan üzerindeki harfler aynı şekilde kullanılmıştır. 


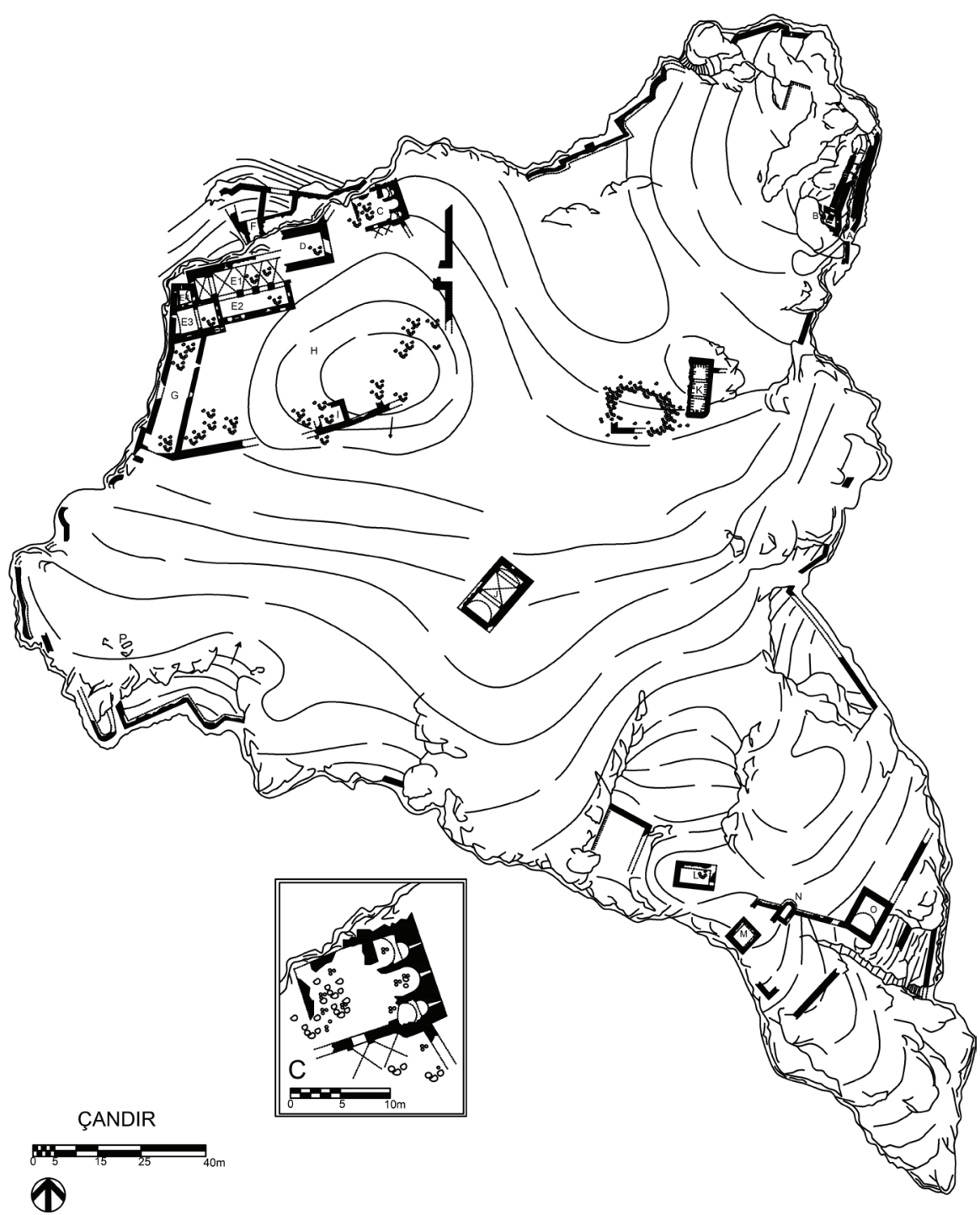

G. 2. Çandır Kalesi Planı, (R. W. Edwards, The Fortifications of Armenian Cilicia, 1987, 104-105 (uygulama: S. Eren, 2019).

Merdivenlerden sonra "B" kapısına ulaşılmaktadır. Kapı içten yarım yuvarlak kemerlidir ve düzgün kesme taş malzemeden yapılmıştır. B kapısının olduğu yer nöbetçi odası formunda düzenlenmiş olup doğu cephesinde bir mazgal pencere bulunur. B bölümünden birkaç merdiven basamağı aracılığıyla iç kaleye ulaşılmaktadır. İki aşamalı ve merdivenli zik zak yapan giriş bölümü, Kilikya bölgesi kaleleri arasında sadece Çandır Kalesi'ne özgüdür (G. 3, G. 4). 


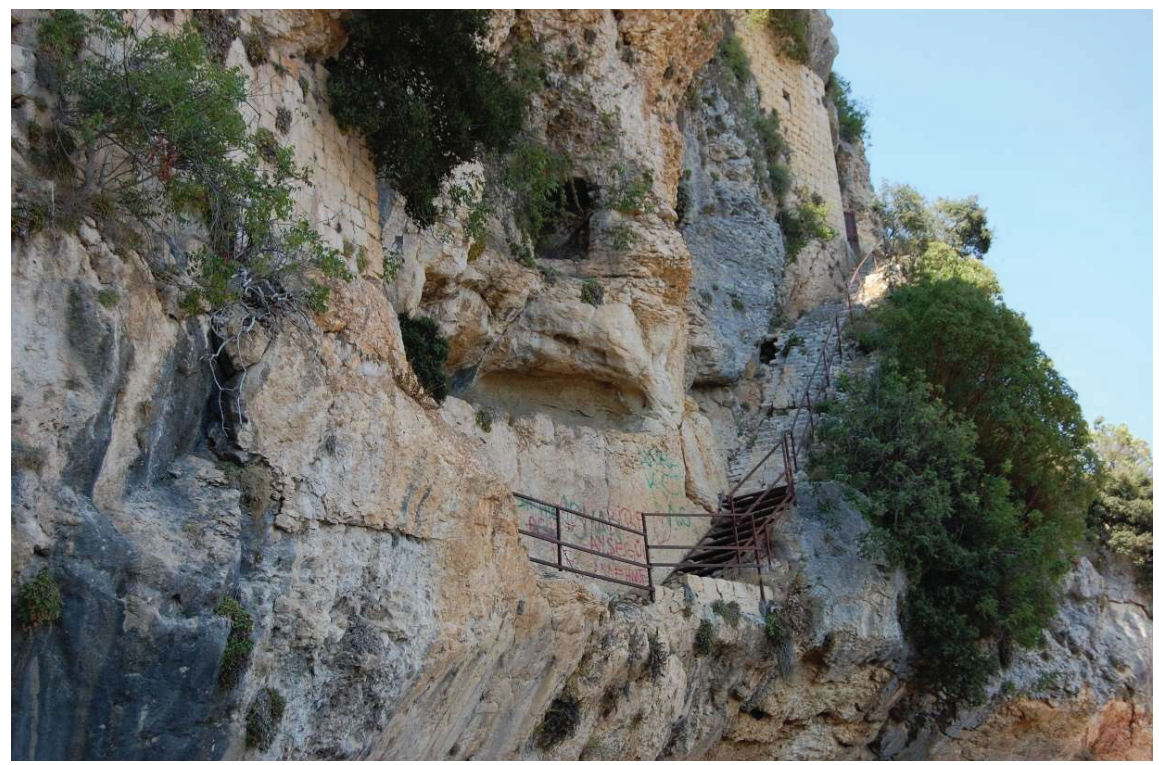

G. 3. Çandır Kalesi kuzeydoğu cephe (H.Sözlü, 2019)

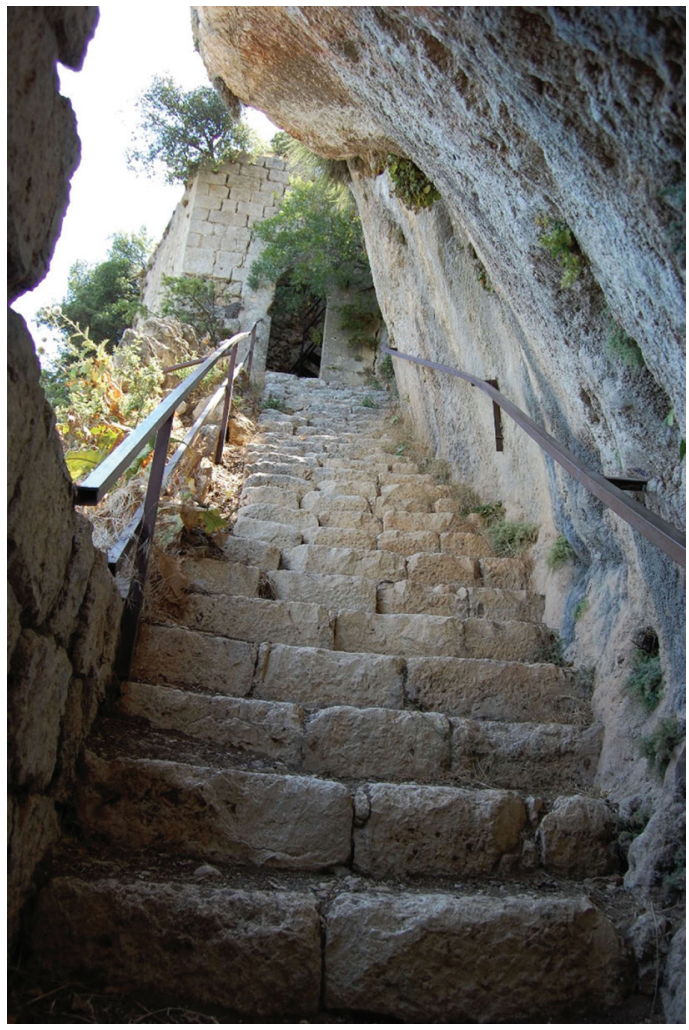

G. 4. Çandır Kalesine çıkışı sağlayan merdivenler (H. Sözlü, 2019). 
İç kale zemini kayalıktır, sert ve aşılması zor bitki örtüsüyle kaplanmış durumdadır. Mimari yapılar daha çok iç kalenin kuzeybatısında yoğunlaşmaktadır. Kalenin güneydoğusunda birkaç küçük yapı kalıntısı günümüze ulaşabilmiştir. Kale yüksek bir konumda ana kaya üzerinde inşa edildiğinden ve vadilerle çevrili olmasından dolayı tüm cephelere sur inşa etme ihtiyacı duyulmamıştır. Daha çok kuzey ve batıda sur görülmektedir. Doğal oluşum ve ana kaya üzerine kurulu olan kalede, mimari elemanlar bu duruma göre konumlanmıştır (G. 5).

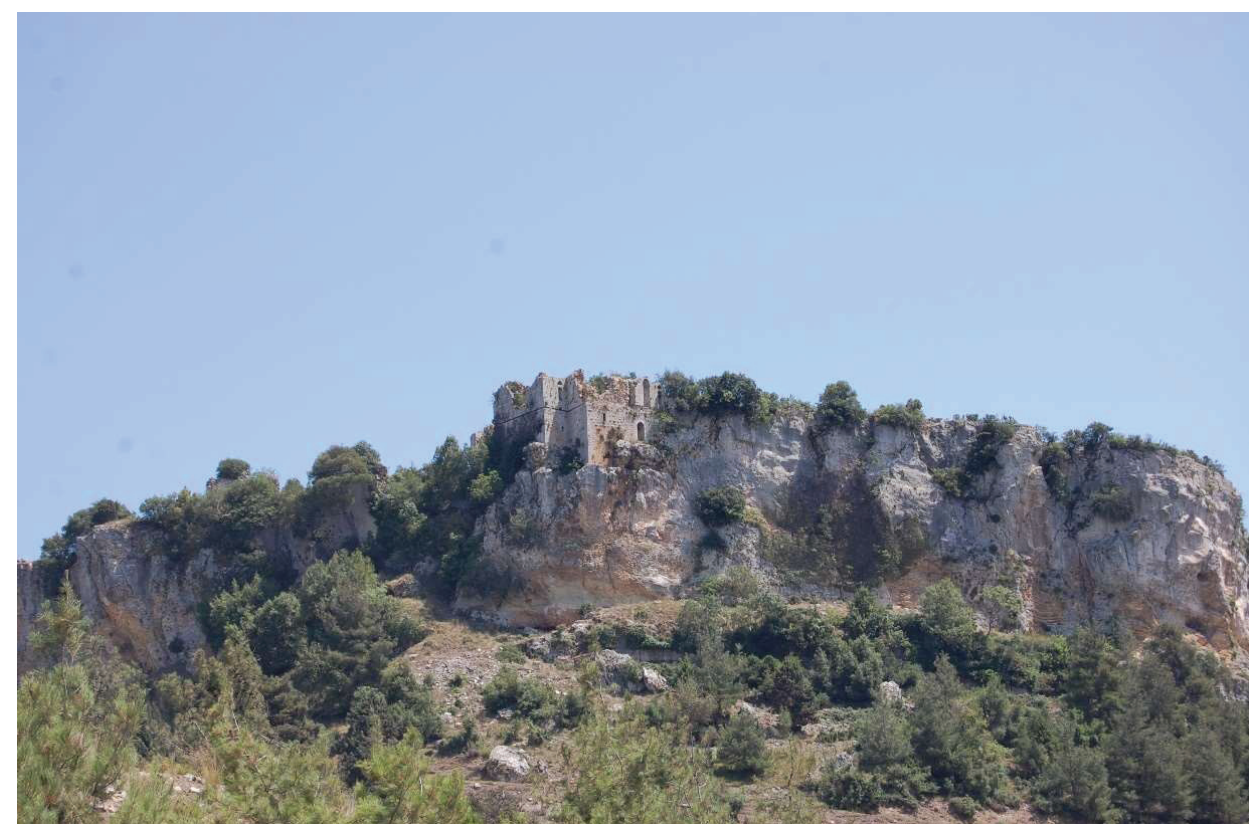

G. 5. Çandır Kalesi genel görünüm (L.Yılmaz, 2019)

Kalede, kilise (C), D yapısı, E yapısı (konut), F yapısı (sarnıç), G yapısı, H (avlu), I yapısı (sarnıç), J yapısı, K yapısı (sarnıç), L ve M yapıları, N yapısı (sarnıç), O yapısı (sarnıç) ve P kalıntısı (olasılıkla lahit) bulunmaktadır.

Kilise (C), Çandır Kale yerleşmesi içinde, iç kalenin kuzeybatısındaki yapılar topluluğunun doğusundadır. Kilisenin en sağlam kısmı doğu cephesidir. Apsisi ve iki tarafında bulunan pastophorion hücreleri günümüze ulaşabilmiştir. Kiliseye ait avlu duvarıysa kısmen mevcuttur. Yapı, doğu-batı doğrultulu olup düzgün dikdörtgen biçimli bir bazilikal zemin planı özelliği taşımaktadır (G. 6). 


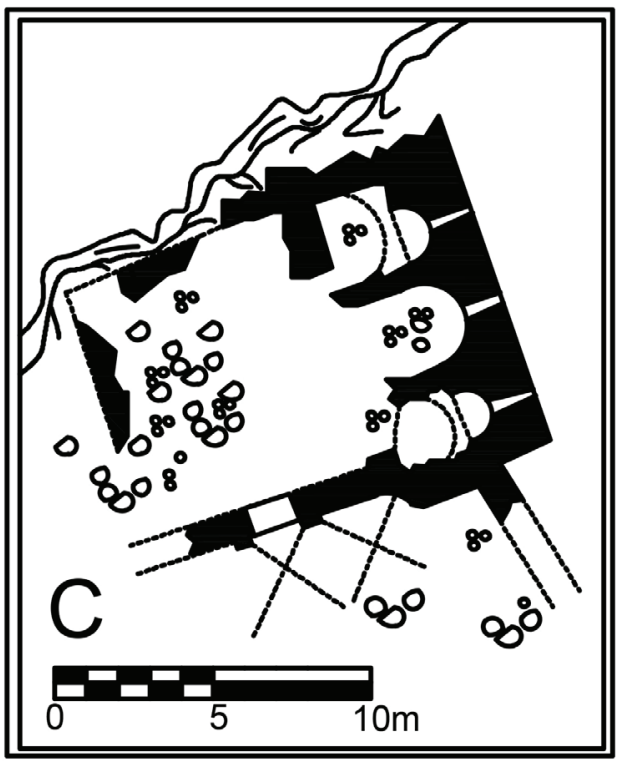

G. 6. Çandır Kale Kilisesi planı. (R. W. Edwards, The Fortifications of Armenian Cilicia, 1987, 104-105 (uygulama: S. Eren, 2019).

Güney duvarındaki yazıta göre kilise, Kral I. Hetum'un kardeşi kale muhafızı Smbat tarafından 1251 yılında babasının anısına inşa edilmiştir. ${ }^{20} \mathrm{Bu}$ yazıt günümüze tam olarak ulaşamamıştır ancak yazıttaki bilgiler ilk kez 1875 yılında P. Sibillian tarafindan yayımlanmıştır. ${ }^{21}$ Yapıda kullanılan düzgün kesme taş işçiliğinin yerel ustaların eseri olmadığı ve taşların Ermeni göçmenler tarafindan getirildiği ileri sürülmüştür. ${ }^{22}$ Düzgün kesme taşta kullanılan bosaj tekniği, bölgede Hellenistik devirlerden itibaren görülebilmektedir. Kilisenin günümüze ulaşan kalıntıları, cephesi kesme taştan örülmüş düz duvarla kapatılmış ana apsis ile pastophorion hücreleri, güney duvarlarının bir bölümü ve kuzeyde bir taş blok üzerinde haçkar kabartması bulunan ek yapının kalıntısıdır. Günümüzde belirlenen kalıntılar olasılıkla üç nefli, kale için çok küçük boyutlu sayılmayacak kilisenin varlı̆̆ını doğrulamaktadır. Cephede kullanılan taşların kısmen yıkılması nedeniyle sadece ana apsisteki mazgal pencere görülebilmektedir.

Yapının doğu cephesindeki duvarın üzerindeki mazgal pencereler, ana apsis, güney pastophorion ve üst kat pastophoriona ait pencereler günümüze ulaşmıştır. Ana apsisin ölçülebilen mazgal penceresinin genişliği $65 \mathrm{~cm}$, boyu $132 \mathrm{~cm}$ 'dir. Mazgal pencerenin üzeri yarım daire kesitli sivri kemerli silme ile sınırlandırılmıştır (G. 7).

20 Robert W. Edwards, "Ecclesiastical Architecture in the Fortifications of Armenian Cilicia," Dumbarton Oaks Papers 36, (1982), 161.

21 Edwards, "Ecclesiastical Architecture in the Fortifications of Armenian Cilicia," 163; bkz. Gottwald, "Die Kirche und das Schloss Paperon in Kilikisch-Armenien," 95.

22 Edwards, "Ecclesiastical Architecture in the Fortifications of Armenian Cilicia," 160-161. 


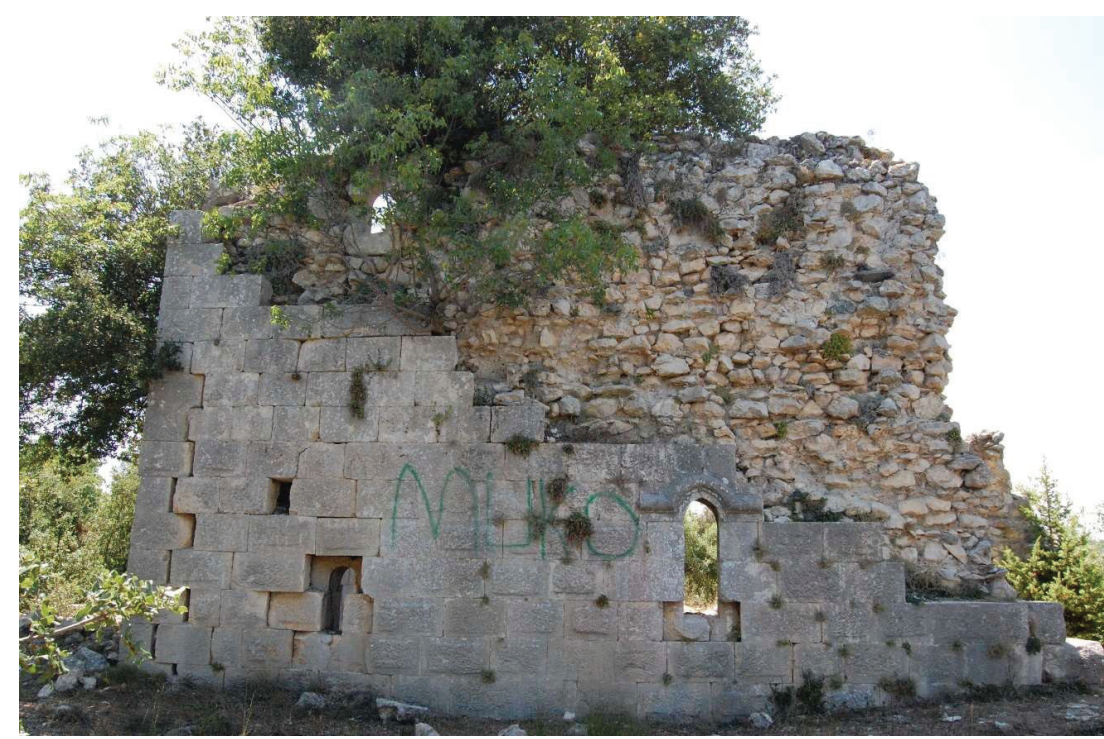

G. 7. Çandır Kalesi, Kilise doğu cephe (H. Sözlü, 2019).

Kiliseyle ilgili erken döneme ait araştırmalarda Gottwald, 1930'lu yıllarda kaleyi ziyaret ettiğinde batı duvarının tamamının, kuzey duvarının batı bölümünün, üst örtünün ve tüm destek yapılarının harap durumda olduğunu belirlemiştir. ${ }^{23}$ Edwards ise 1979 yılında gerçekleştirdiği araştırmasında (Gottwald'dan farklı olarak), yapının güneydoğusundaki apsisin zorlukla görülebilir durumda olduğunu, kuzey duvarın batısının yazıtla birlikte tamamen yok olduğunu, koro bölümünün kuzey köşesinin y1kıldığını tespit etmiştir. ${ }^{24}$ Yapının durumu, Edwards'ın kaydettiği yıkımın artarak sürdüğünü göstermektedir. Edwards karşılaştırma için Anavarza'daki I. Toros tarafından yaptırılan kiliseyi değerlendirmiştir. Her iki yapıda da iç ve dışta kullanılan düzgün kesme taş bloklar, çimento ve moloz taşla bağlanmıştır. Çandır Kale Kilisesi'nin nef duvarları $76 \mathrm{~cm}$ kalınlığında olarak belirlenmiştir. Kireçtaşı bloklar Anavarza kilisesindeki örneklerle aynı boyuttadır ancak Edwards, Smbat'ın inşa ettirdiği Çandır Kale kilisesinin daha özenli yapıldığını söylemektedir. ${ }^{25}$ Yapı, düzgün kesme taş arasında moloz taş örgüyle oluşturulan sandık duvar tekniğinde inşa edilmiştir ve günümüze sınırlı sayıda süsleme ulaşmıştır. Gottwald, küçük apsisin içinde fresko kalıntıları olduğunu kaydetmiştii ${ }^{26}$ ancak yapıda günümüze ulaşan fresko kalıntısı belirlenememiştir. Hellenkemper'e göre bu mekân bir yan narteks işlevindedir. ${ }^{27}$ Edwards, Gottwald'ın görüşüne katılarak yapının bir ek şapel olduğunu yazmıştır. ${ }^{28}$ Gottwald,

23 Gottwald, "Die Kirche und das Schloss Paperon in Kilikisch-Armenien," 86.

24 Edwards, "Ecclesiastical Architecture in the Fortifications of Armenian Cilicia," 162.

25 Edwards, "Ecclesiastical Architecture in the Fortifications of Armenian Cilicia," 160.

26 Gottwald, "Die Kirche und das Schloss Paperon in Kilikisch-Armenien," 94.

27 Friedrich Hild ve Hansgerd Hellenkemper, Kilikien Isaurien (Wien: Verlag der Österreichhischen Akademie der Wissenschaften, 1990), 374.

28 Edwards, "Ecclesiastical Architecture in the Fortifications of Armenian Cilicia," 162. 
apsisli yapının kiliseden sonraki bir tarihte inşa edildiğini öne sürmüştür. ${ }^{29}$ Ek şapel ve kiliseyle güneydeki küçük apsisli ek mekânda çıkıntılı duvarın sürekliliği ve bu şapelin kuzeydoğu köşeyle birleşen düzgün görünümü, Edwards’1 bu yapıların aynı devirde inşa edildiği sonucuna ulaştırmıştır. ${ }^{30}$ Kilikya bölgesinde ana kilise yapısına bitişik inşa edilmiş ek yapı ve şapellerin bulunduğu örnekler mevcuttur. Korykos J bazilikası, ek şapel yapısının mevcut olduğu Erken devir Bizans kilisesidir. ${ }^{31}$ Aya Tekla bazilikası ile Susanoğlu kilisesinde yapının güneyinde yer alan, apsisi olmayan yan narteks olarak değerlendirilebilecek ek yapı örnekleri bulunmaktadır. ${ }^{32}$

Gürcistan, Mtsheta'da 1130 yıllarına ait Samtavro Katedrali planında (G. 8), güneyde yer alan apsisli ek mekân bağlamında Çandır Kale Kilisesi'nde haçkar kabartmasının yer aldığ 1 ek mekânla benzerlik kurulabilmektedir. 1106 tarihli Gelati Manastır Kilisesi'nde ana mekânla bağlantılı ek şapel yapıları dikkat çekmektedir. Benzer ek mekân içeren Gürcü kilise örnekleri, güneyde inşa edilen ek mekânıyla yonca planlı Nikortsminda, Aziz Nikolaos Kilisesi, güney ve kuzeydeki apsisli ek mekânlarıyla Gelati Manastırı'ndaki Meryem Ana Kilisesi ${ }^{33}$ sayılabilir (G. 9). Bu yapılar doğrultusunda Ortaçağ'da kuzeyde Gürcistan'dan Türkiye'nin kuzeyi ve doğusuna ve sonunda Kilikya bölgesine ulaşan geleneksel bir dinî mimari plan tipi görülebilmektedir.

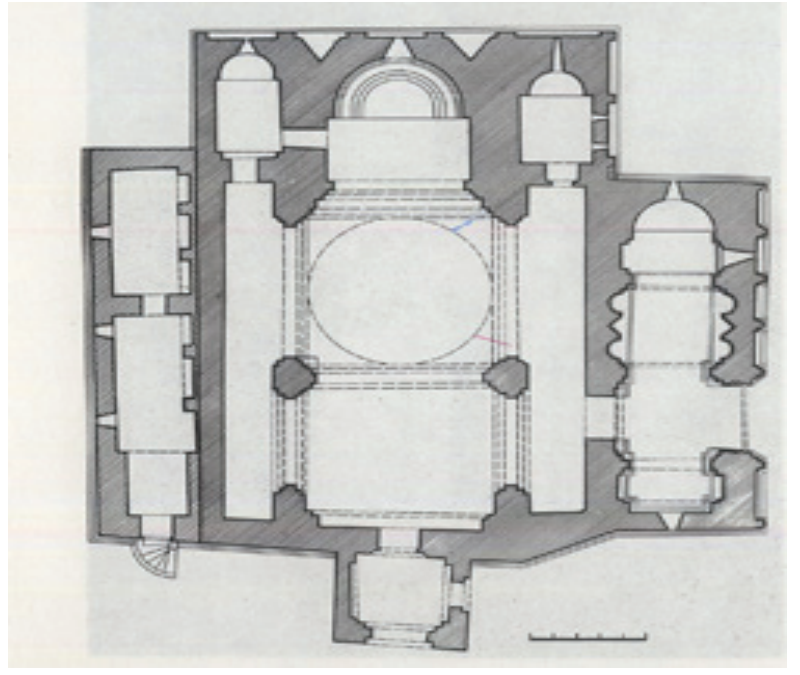

G. 8. Samtavro Katedrali,

http://www.dzeglebi.ge/dzeglebi/s/samtavro.html

29 Gottwald, "Die Kirche und das Schloss Paperon in Kilikisch-Armenien," 94.

30 Edwards, "Ecclesiastical Architecture in the Fortifications of Armenian Cilicia," 162.

31 Stephen Hill, The Early Byzantine Churches of Cilicia and Isauria, ed. A. Breyer ve J. Haldon, (Hampshire: Variorum 1996), 139; ayrıntılı bilgi için bkz. E. Herzfeld ve S. Guyeu, Meriamlik und Korykos, Zwei Christliche Ruinenstatten Des Rauhen Kilikiens (Manchester: Manchester University Press, 1930).

32 Hill, The Early Byzantine Churches of Cilicia and Isauria, 217, 243.

33 Mine Kadiroğlu ve Bülent İşler, Gürcü Sanatının Ortaçağı (İstanbul: Bilgin Kültür Sanat, 2010), 117-118. 


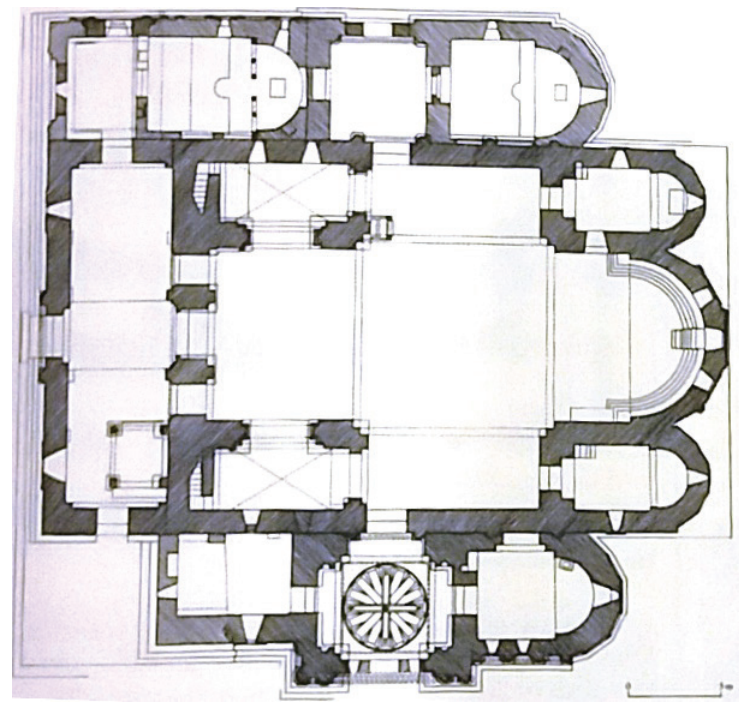

G. 9. Gelati Manastır Kilisesi,

Bülent İşler, "Gürcü ve Bizans Kiliselerinde Onbirinci ve Onüçüncü Yüzylllara Tarihlendirilen Ek Mekanlar", 2010, 403.

Çandır Kale Kilisesi’nin kuzeyinde ek şapel olarak tanımlanan mekânda haçkar kabartması bulunmaktadır. Bu haçkar kabartmasını çevreleyen iki çıkıntılı bordür, geçmeli halat motiflidir. Haçkar kabartmasının boyu 1.30 m, genişliği 1.15 m olarak ölçülmüştür. Geometrik motifli dış bordürün genişliği 10 cm'dir (G. 10).

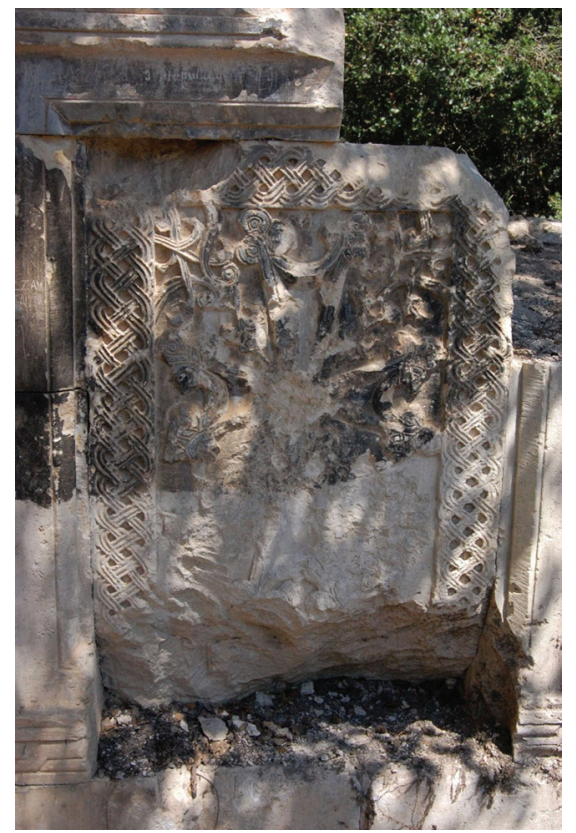

G.10. Çandır Kalesi Kilisesi haçkar kabartmalı taş blok (H. Sözlü, 2019). 
Gottwald'ın görüşüne göre tonozlar, kilisenin güney duvarından çıkan ek şapelin üst örtüsünü taşımaktadır. ${ }^{34}$ Edwards, araştırmasında bu tonozların, ek şapelin bir bölümünü taşıdığını öne sürmüştür. ${ }^{35} \mathrm{Bu}$ durum yapının her dönemde büyük ölçüde tahrip olduğunu göstermektedir. Edwards, yapıda anıtsal yazının yer aldığı bir bölümün yer aldığını belirtilen nef portalini kaydetmiştir ${ }^{36}$, ancak portal ve yazıt günümüze ulaşamamıştır. Yapının üst örtüsüne ilişkin günümüze ulaşmış herhangi bir kalıntı bulunmamaktadır. Kilisenin kuzey cephesi tanımlanamayacak ölçüde yıkılmıştır. Pastophorion hücreleriyse küçük apsisli ve küçük tonozla örtülü birer odadan oluşmaktadır (G. 11).

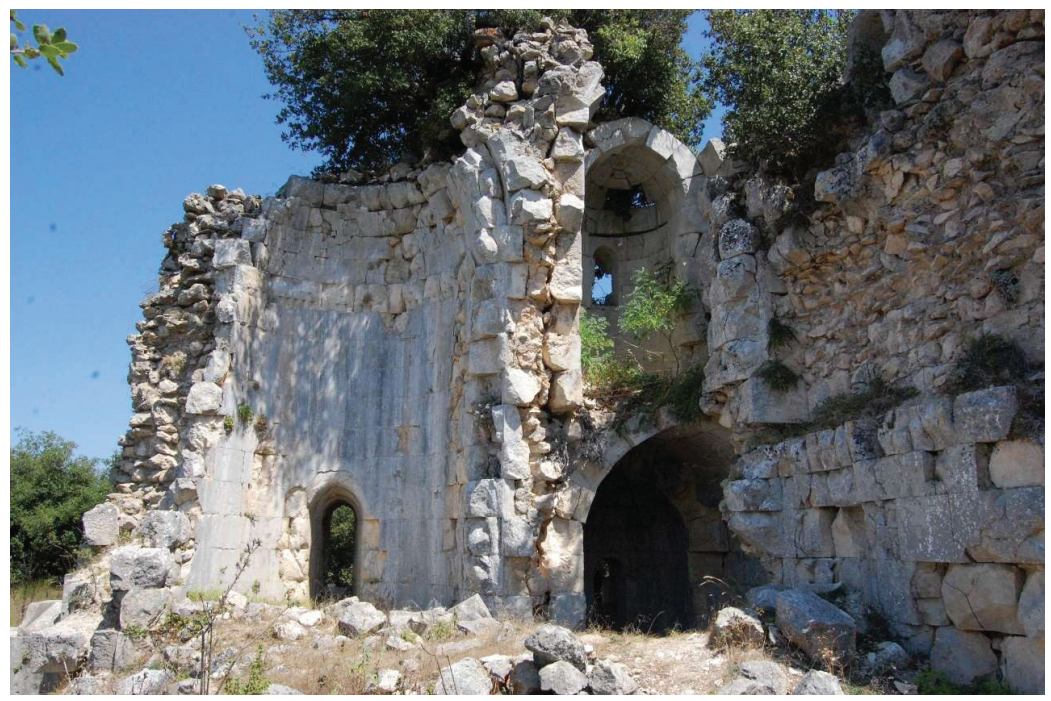

G.11. Çandır Kalesi Kilisesi, apsis ve kuzey pastophorion hücresi (H. Sözlü, 2019).

İki katlı olduğu üst kattaki mazgal pencerelerden anlaşılan yapıda günümüze ulaşan herhangi bir merdiven kalıntısına rastlanmamıştır. Gottwald ve Edwards, kale muhafızı Smbat'ın kiliseyi I. Toros'un Anavarza'daki kilisesine benzer planda inşa ettirdiğine işaret etmiştir. ${ }^{37} \mathrm{Nef}$, apsis yönüne dikey uzanan payelerle bölündüğünü göstermektedir. Yapının günümüzde görülen boyutlarından neflerin geniş olmadığ 1 anlaşılmaktadır.

Edwards, kilisenin iki katlı ve bu nedenle toplam dört pastophorionu olduğunu ve üst katta pastophorion hücrelerinin bulunduğunu yazmıştır. Bu bakımdan Ermenistan, Goshavank’taki 1237 tarihli St. Gregory Kilisesi'ni örnek göstermiştir. ${ }^{38}$ Bu kilise

34 Gottwald, "Die Kirche und das Schloss Paperon in Kilikisch-Armenien," 100.

35 Edwards, "Ecclesiastical Architecture in the Fortifications of Armenian Cilicia," 162.

36 Edwards, "Ecclesiastical Architecture in the Fortifications of Armenian Cilicia," 163.

37 Gottwald, "Die Kirche und das Schloss Paperon in Kilikisch-Armenien," 93; Edwards, "Ecclesiastical Architecture in the Fortifications of Armenian Cilicia," 162.

38 Edwards, "Ecclesiastical Architecture in the Fortifications of Armenian Cilicia," 164. 
merkezi kubbelidir ve çift eğimli çatı örtü sistemi uygulanmıştır. ${ }^{39}$ Yapıya ait çan kulesi olabilecek herhangi bir kalıntıya rastlanmamıştır.

Kapalı haç planının iki veya dört serbest destekle uygulandığı bu plan tipinde doğudaki apsis, bazen iki katlı olabilmektedir. Çandır Kale Kilisesi'nde apsis ve pastophorionda yer alan pencere kalıntılarından yola çıkılarak benzer durumun burada da olabileceği öne sürülmüştür.

D yapısı kilisenin batısında olup günümüze kuzey, güney ve doğu duvarı kalıntıları ulaşabilmiştir. Doğu-batı yönünde dikdörtgen planlı olduğu, üzerindeki tonoz örtüsü izlerden anlaşılmaktadır. İşlevi anlaşılamayan bu yapı, büyük olasılıkla batısında yer alan E kompleksiyle bağlantılıdır. Çünkü D yapısının kalıntıları E'ye kadar uzanmaktadir.

E yapısı iki katlı bir konut biçiminde planlanmıştır. Burası yönetici kesimin kaldığı yapı olarak yorumlanabilir. Hem plan açısından hem süsleme unsurlarının bulunması hasebiyle burası kale içerisinde ayrı bir önem taşımaktadır. Kendi içerisinde dört bölüme ayrılmış olup iki katlı bir düzene sahiptir. Ayrıca kalenin en korunaklı yerinde bulunmaktadir (G. 12).

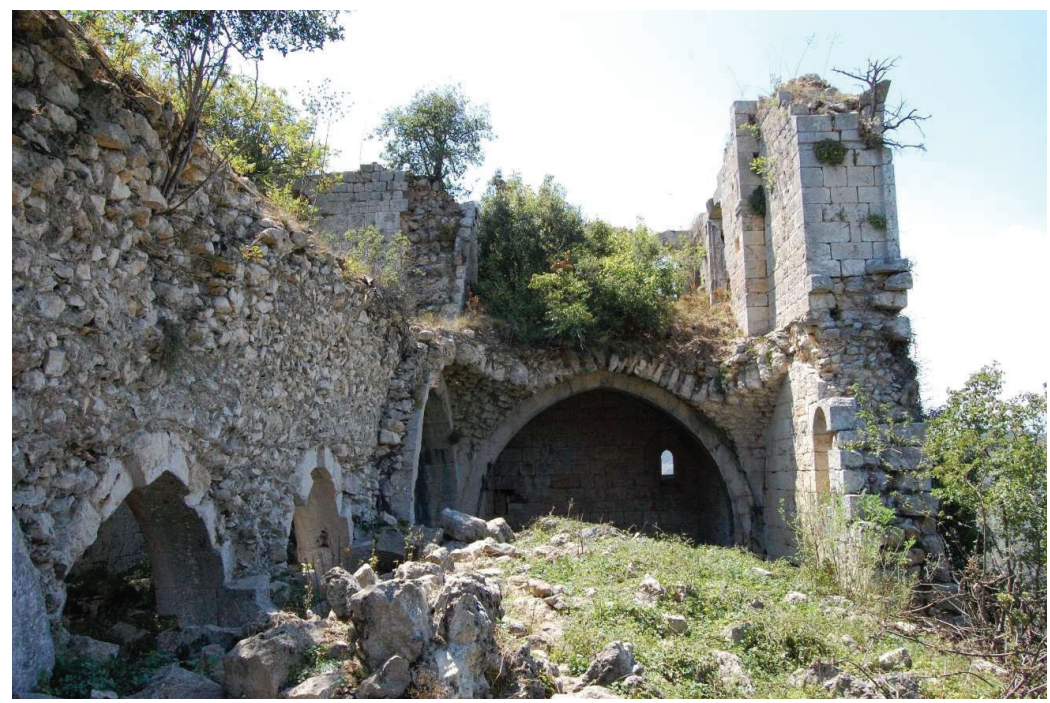

G. 12. Çandır Kalesi E Konut yapısı (H. Sözlü, 2019).

E1 bölümü doğu-bat1 yönünde dikdörtgen bir plana sahip olup üst örtüsü ve kuzey duvarının tamamına yakını yıkılmış durumdadır. Güneyindeki E2 bölümüne açılan sivri kemerli dört açıklık bulunmaktadır. Doğudaki birinci kemer $2.13 \mathrm{~m}$, ikinci kemer 1.87 m, üçüncü kemer 1.97 m genişliğindedir. Kemer ayaklarının güney yüzünde ahşap hatıl veya gergilerin yerleri mevcuttur. E1 mekanının kuzey duvarı büyük

39 “St. Gregory Church”, erişim 08.05.2019, www.armenianhighland.com/churches/chronicle450.html 
ölçüde yıkılmıştır. Kuzey duvarın batı ucunda iki katlı pencere düzeni olduğu kalan pencerelerden anlaşılmaktadır. E1'in üzerinin kalan izlerden çapraz tonozla örtülü olduğu tahmin edilmektedir. Mekânın batı ucunda, üzeri çapraz tonozla örtülü ve 5.25 m genişliğindeki sivri kemerli bir geçişle bağlanan kuzey-güney yönünde dikdörtgen planlı küçük bir bölüm vardır (G. 13).

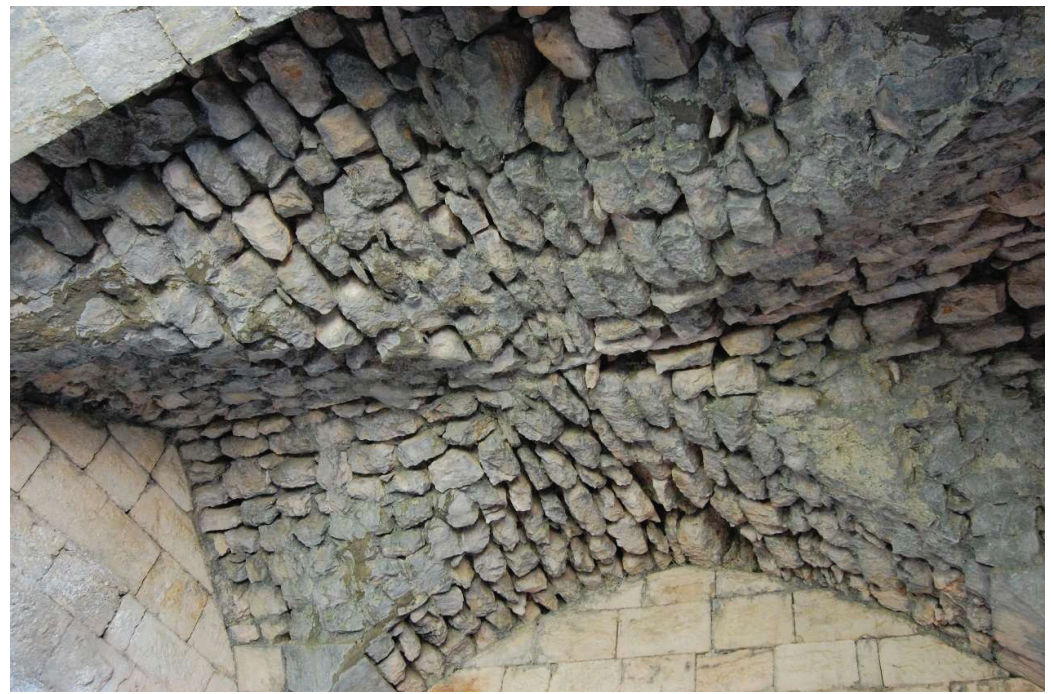

G. 13. Çandır Kalesi E Konut yapısı E1 bölümü üst örtüsü (H. Sözlü, 2019).

E1 bölümünde bulunan kemerlerde ve kemer iç yüzeylerinde düzgün kesme taş malzeme kullanılmıştır. Üst örtüde moloz taş ve kaba yonu taş kullanılmıştır. Bu bölümde uygulanan duvar işçiliği kaliteli olup düzgün kesme taşların arasında hiç boşluk bırakılmamıştır. E1'in alt katı çok fazla yıkık olduğu için üst katı hakkında bilgi sahibi olmak zordur. Katlar arasındaki ayrım dış cephedeki ahşap hatıl yuvalarından anlaşılmaktadır.

E2 mekanı doğu batı yönünde dikdörtgen planlı ve iki katlıdır ve doğu duvarında $\mathrm{H}$ avlusuna açılan bir kapı yer almaktadır. Bu bölümün güney duvarında ikisi alt kat seviyesinde, dördü üst kat seviyesinde açılan altı adet dikdörtgen biçimli pencere bulunur. Bu biçimdeki pencerelere kalelerde sıklıkla rastlanılmamaktadır. Mekânın sivil bir konut olması nedeniyle dikdörtgen pencereler tercih edildiği öne sürülebilir. Avluya bakan cephede bulunması mekânın daha ferah hâle getirilmesi amacını taşıdığını düşündürmektedir. Ayrıca güney duvarı doğu ucunda kapı açıklığı bulunmaktadır. Mekânın batı duvarından E3 bölümüne geçilmektedir. E2 mekânının ikinci katı yıkılmış durumda olduğu için üst örtüsü hakkında fikir sahibi olunamamaktadır. Yalnızca üst katın doğu ve batı duvarlarında yarım yuvarlak formlu pencere açıklıkları günümüze ulaşabilmiş̧ir. Yarım yuvarlak kemer formlu kapıların üzerinde ahşap hatıl boşlukları mekânı dört yönden çevrelemektedir (G. 14). 


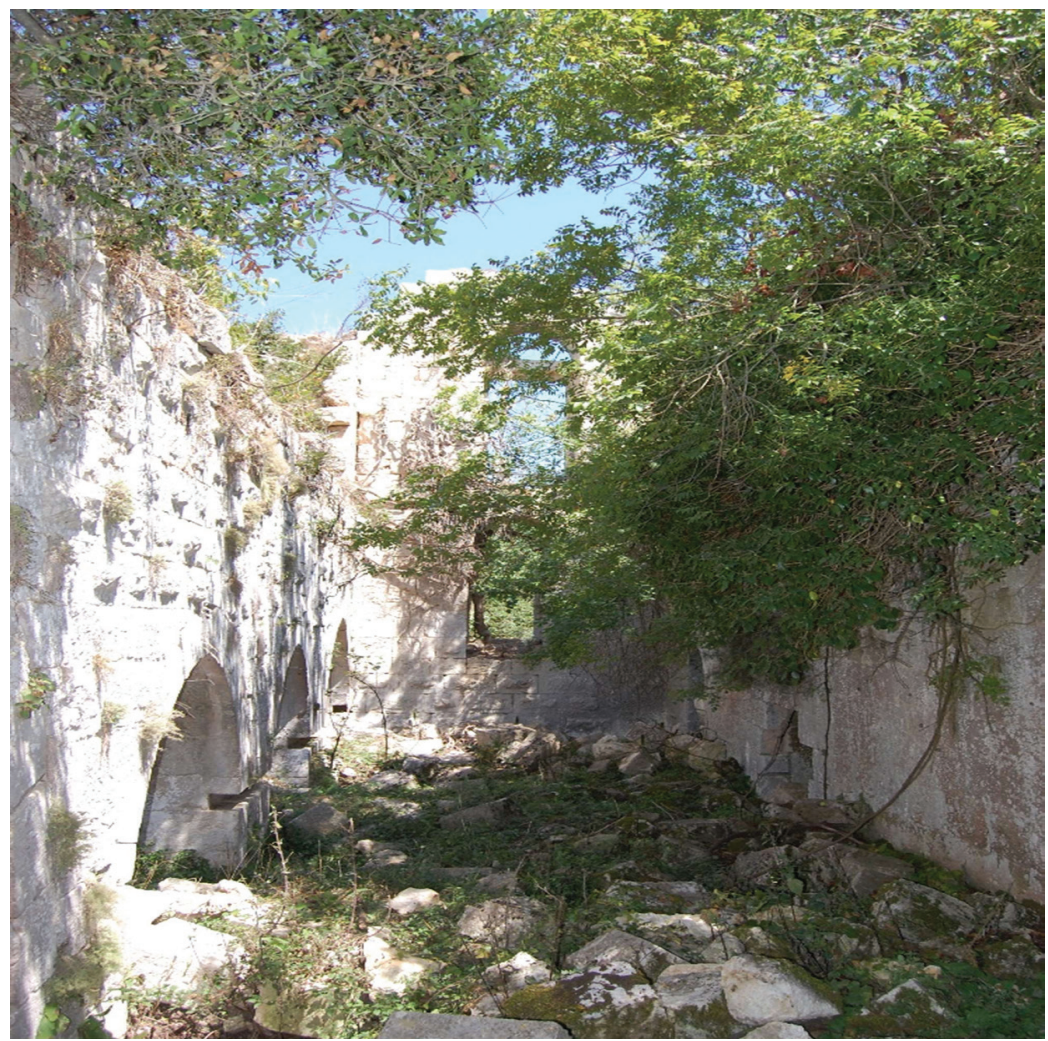

G. 14. Çandır Kalesi E Konut yapısı E2 bölümü (H. Sözlü, 2019).

E3 bölümü, E1 ve E2 mekânları gibi doğu ve batı yönünde dikdörtgen planlı ve iki katlıdır. Bu bölüme giriş doğu duvarında açılan 1.15 m genişliğindeki sivri kemerli kapıdan sağlanmaktadır. Kapının güneyinde $87 \mathrm{~cm}$ genişliğinde ve $1.30 \mathrm{~m}$ yüksekliğinde bir niş yer almaktadır. Alt katın üst örtü tipi günümüze sağlam şekilde ulaşamamakla birlikte, mekânın ortasında üst örtüyü destekleyen tonoz kemer kalıntısı mevcuttur. Ayrıca üst kat zemini seviyesinde duvarlarda ahşap hatıl izleri görülmektedir. Güney duvarında üst kata çıkış amacıyla açılmış olan kap1 ve bir niş bulunmaktadır. Sivri kemer formlu bu kap1, giriş holü şeklinde olup üzeri çapraz tonozla örtülüdür. Buradan duvar içerisine yerleştirilmiş olan merdivenlerle üst kata çıkılmaktadır. Güney duvarı batısında bulunan niş düz lentoludur. Niş, üst kata baca şeklinde bir açıklıkla bağlanmaktadır. Nişin lentosunun doğusunda iki sıra mukarnastan oluşan bir süsleme yer almaktadır (G. 15). Üst sıradaki mukarnaslar istiridye kabuğu formuyla sonlanmış durumdadır. E yapılarında tespit edilebilen tek süsleme unsuru bu olmuştur. Süsleme detayı nedeniyle yapının bu bölümünün daha önemli bir konuma sahip olduğu öne sürülebilir. 


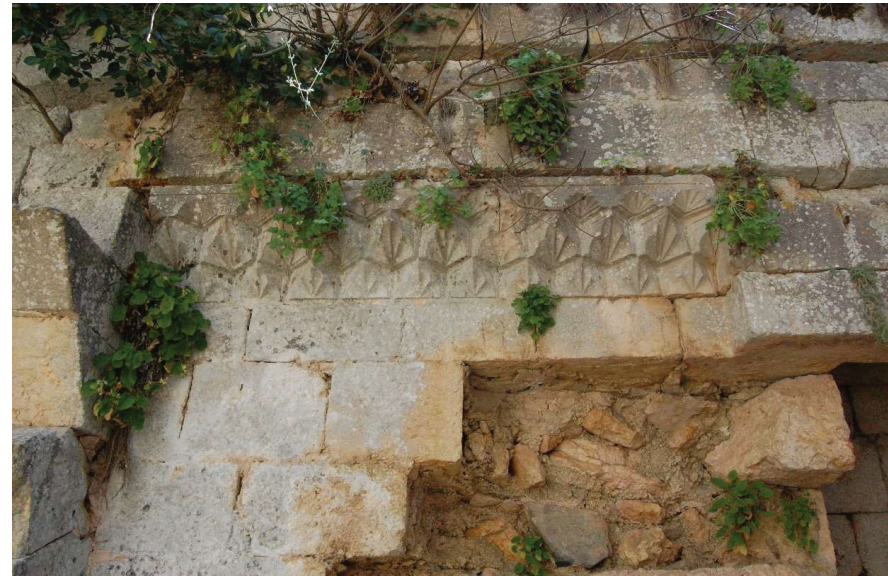

G. 15. Çandır Kalesi E Konut yapısı E3 bölümü mukarnas süslemesi (H. Sözlü, 2019).

Bu mekânda da düzgün kesme taşla birlikte bosajlı taş (G. 16) ve düzenli inşa tekniği uygulanmıştır.

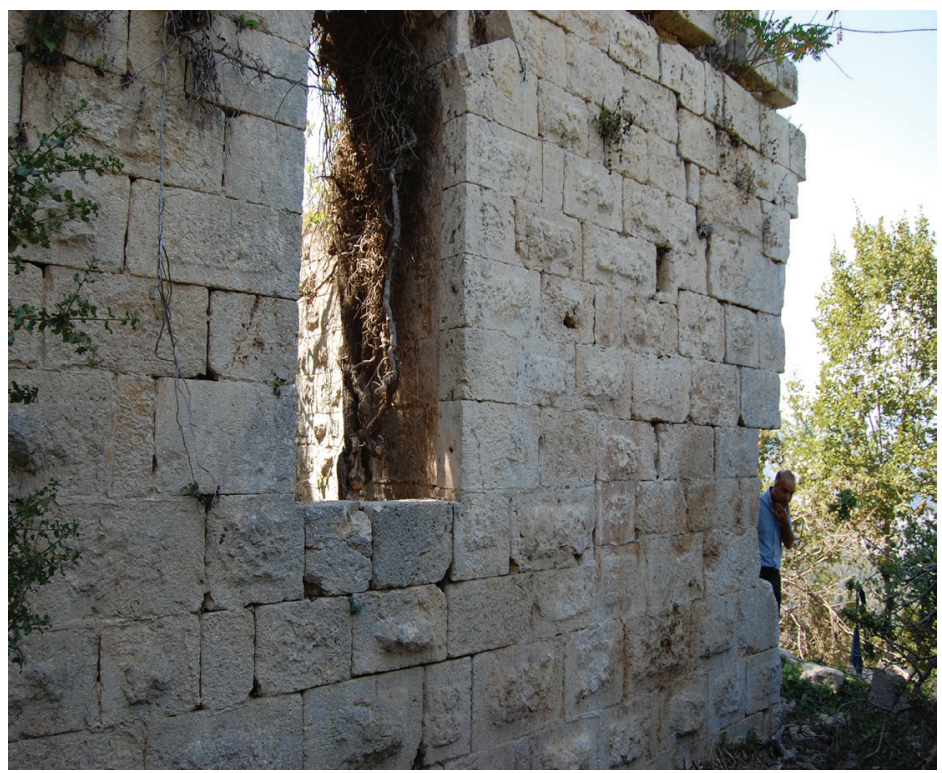

G. 16. Çandır Kalesi E Konut yapısı bosajıı taş kullanımı (H. Sözlü, 2019).

Alt kat seviyesinde batı duvarı ortasında sivri kemer formlu kapı yer alır. İkinci kat seviyesinde ise batıda yuvarlak kemerli üç, kuzey duvarında dikdörtgen formlu iki doğu duvarında ise dikdörtgen formlu yarım yuvarlak kemerli bir açıklık bulunmaktadır. E3 yapısının ikinci katına ait örtü sistemi belirlenememiştir (G. 17). 


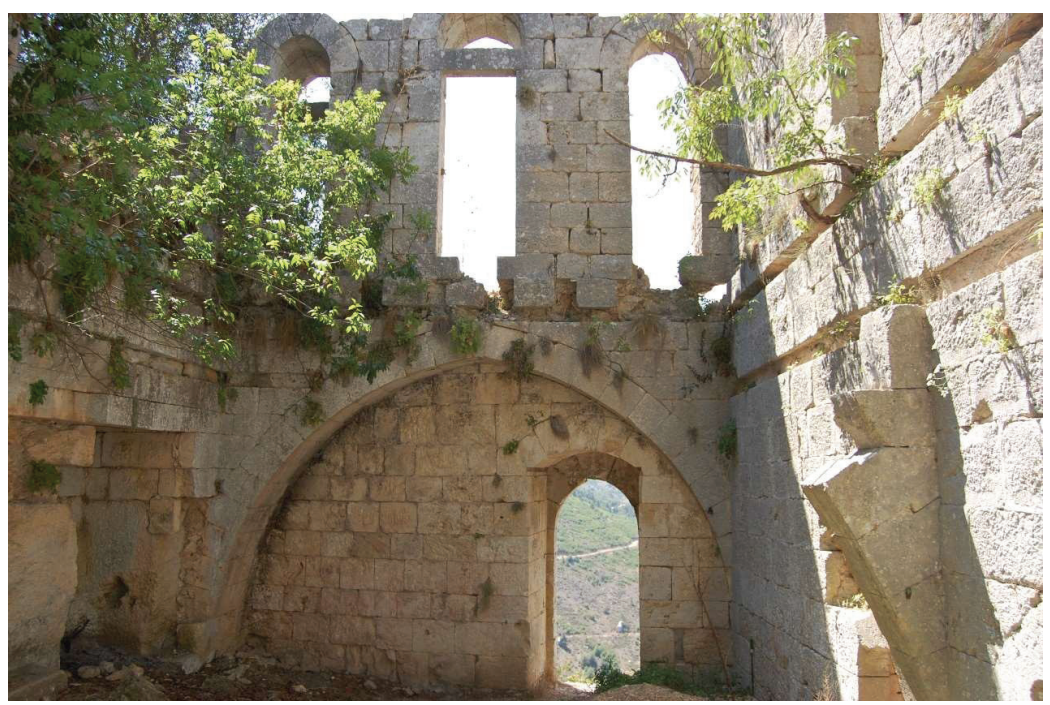

G. 17. Çandır Kalesi E Konut yapısı E3 bölümü (H. Sözlü, 2019).

E4 bölümü, E3’ün kuzeyinde yer alan kareye yakın dikdörtgen planlı ve küçük ölçekli bir kısımdır. Mekânın batıya ve güneye açılan birer mazgal penceresi vardır. Bu bölüme giriş E3'ün ikinci katından sağlanmaktadır. Edwards, bu mekânın alt katının sivri kemerli tonozla örtülü olduğunu, duvarlarında alçı malzemenin bulunduğunu belirtmektedir. ${ }^{40}$ Günümüzde bu alçı süslemelerden herhangi bir iz görülmemektedir.

E bölümü yapıları, kalenin en önemli ve en dikkat çekici kısımlarının olduğu büyük bir konut izlenimi vermektedir. İki katlı odaların olması, plan ve mimari özellikleri bakımından çeşitlilik barındırması, süslemenin az da olsa yer alması, duvar içerisinden verilen merdivenle üst kata çıkılması, küçük geçiş yerlerinde çapraz tonozun tercih edilmesi gibi özellikler bu düşüncemizi desteklemektedir. Yine E yapılarındaki düzgün kesme taş blokların üzerinde taşçı işaretleri görülmektedir. Tespit edilen bu taşçı işaretleri (+) biçimindedir. Çandır Kalesi'ne yakın olan, Gözne, Belenkeşlik, Sinap Kalelerinde taşçı işaretlerine rastlanmamıştır. Silifke Kalesi’nde farklı şekillerde taşçı işareti görülmüştür ancak Çandır Kalesi'nde tespit edilen işaretle aynı olmadıkları anlaşılmıştır. E yapılar topluluğunun kuzeyinde, kale seviyesinden biraz daha düşük seviyede üzeri tonoz örtülü F mekânı bulunmaktadır. Mekânın içerisindeki sıvalardan hareketle burasının sarnıç olabileceği düşünülmektedir.

G yapıs1, E3 bölümünün kuzeyinde $H$ avlusunun batısında olup kuzey-güney yönünde dikdörtgen planlıdır. Mekânın içi, sert ve dikenli bitki örtüsüyle kaplı olduğundan tamamı incelenememiştir. G yapısının güney duvarı $\mathrm{H}$ avlusunun duvarıyla oluşturulmuştur. G'nin doğu duvarında iki kapı açıklığı bulunmaktadır. H avlusu E yapılarını, kiliseyi, G yapısını, D yapısını, F yapısını ve I yapısını doğu ve güney

40 Edwards, The Fortifications of Armenian Cilicia, 108-109. 
yönden çevreleyerek iç kale içerisinde ikinci bir iç kale görünümü yaratmaktadır. Bu küçük avlunun dışında kalan yapılar kalenin güney ucuna doğru dağınık bir şekilde yerleştirilmiştir.

I yapıs1, H avlusunun güney duvarına bitişik olarak yapılmıştır. Buranın sarnıç olabileceği düşünülmektedir. J mekânı, iç kalenin ortasında ve $\mathrm{H}$ avlusunun güneydoğusunda bulunmaktadır. Kuzeydoğu - güneybatı uzantılı dikdörtgen planlı bir yapıdır.

Üst örtü içten iki adet sivri kemerle desteklenmektedir. Mekânın işlevi tam olarak anlaşılamamıştır. K yapısı, $\mathrm{H}$ avlusunun doğusunda olup doğu-batı yönünde dikdörtgen planlı bir sarnıçtır. L ve M yapılarının işlevleri ve türleri tam olarak tespit edilememiştir. $\mathrm{N}$ ve $\mathrm{O}$ yapısının duvarları sıvalı olduğu için buraların sarnıç olma ihtimali kuvvetle muhtemeldir (G. 18). Yapılarda belirlenen sıva kalıntıları sarnıç olarak inşa edildiklerine işaret etmektedir. Ayrıca bu sarnıçlar, konum bakımından yalıtılmış bir noktada yer alan büyük boyutlu kalenin su ihtiyacını karşılama zorluğunun göstergesidir.

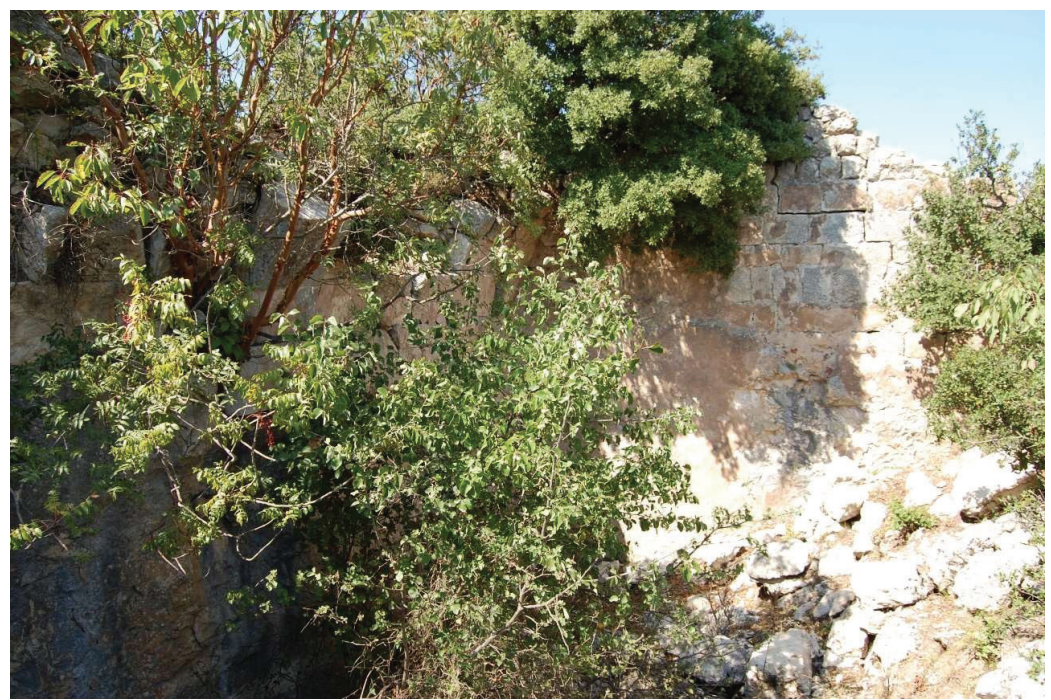

G. 18. Çandır Kalesi O yapısı (H. Sözlü, 2019).

\section{Sonuç}

Kilikya bölgesinde geniş coğrafi alanda inşa edilmiş kaleler, belirli ortak özelliklere sahiptir. Tarih boyunca kaleler ve gözetleme kuleleri, jeostratejik önem taşıyan ana yollar veya kavşaklar üzerinde inşa edilmiştir. Kaleler, ana kaya üzerinde yükselerek çok korunaklı biçimde yapılmıştır. Kaleyi çevreleyen dik yamaç veya uçurumlar bulunmaktadır. Kaleye aşamalı girişlerle kalenin savunulması ve korunması artırılmıştır. Ayrıca gerekli görülen cephelerde çift sur inşa edilmiştir. Yakın coğrafyada bulunan kaleler, birbirlerini görebilecek ve iletişim kurulabilecek biçimde konumlanmıştır. 
Kaleye saldırı durumunda saldırıyı gerçekleştiren orduları en zor cepheye (dik yamaca) yönlendirme kaygısı güdülmüştür. Kaleye ait burçların büyük bir bölümü dairesel planlı ve iki katlıdır. Kale inşasında kullanılan malzeme, bölgede bulunan taşlardan elde edilmiştir. Yapıların ve surların inşasında kaba yonu taş ve düzgün kesme taş kullanılmıştır. Silifke Kalesi hariç olmak üzere kalelerde hendek sistemi görülmemektedir. Kalenin giriş kapıları sur ve burçlarla korunmaktadır. Deniz kıyısında yer alan kaleler, deniz ticaretinde önem taşımaktadır. Kalelerin tamamına yakını Roma ve Bizans döneminde inşa edilmiştir. Kalelere ait çok sayıda sarnıç bulunmaktadır. Farklı büyüklüklerde bazilikal planlı kilise veya şapel yapıları inşa edilmiştir. Kalelerde süsleme öğeleri ve yazıtlar az sayıdadır. Kozan Kalesi gibi bazı örneklerde sonraki dönemlerde yapılan eklemelerle ilgili kitabeler bulunmaktadır. Kalelerin içindeki mekânların üst örtüleri genellikle beşik tonoz, giriş bölümlerindeyse çapraz tonoz tercih edilmiştir. İç kalede surlarla birlikte sura paralel uzanan uzun dehlizler ya da koğuşlar bulunmaktadır.

Kilikya bölgesinde kuzey-güney bağlantısında olduğu kadar doğu ve batı yönlerinde de kale ve gözetleme kulesi inşalarının yoğun olması, çağlar boyunca söz konusu ana ve ara yollardan oluşan güzergâhların askeri ve sivil amaçlarla kullanıldı̆̆ını göstermektedir.

Erken örnekler değerlendirildiğinde Kilikya bölgesinde Mersin'de Silifke-Erdemli arasında yer alan Olba' da Helenistik dönem kule yapılarının askeri ve sivil amaçları bir arada taşıdığı öne sürülmüştür. ${ }^{41}$ Bölgede inşa edilen kuleler, askeri gözetleme ve savunmaya yönelik yapılar oldukları gibi bölgenin yöneticisine (Lord, Bey) ait konut işlevi taşıyan yapılar da olabilmektedir. Aynı zamanda maliki olduğu tarım arazilerini koruma ve ürün depolama işlevi de bulunmaktadır. Olba'da kale, kule, konut ve mezar yapılarında ortak özellik, bosajlı polygonal taşlar kullanılarak inşa edilmesidir. Mancınıkkale'de ise üç ayrı tipte duvar tekniği, Çatıören Tapınağı yapılarındaysa düşmana açık olan batı ve kuzey duvarlarında bosajlı örgü kullanılmıştır. Bu tür kule olarak adlandırılan yapıların feodal beylerin konutları olduğu öne sürülmektedir. Bölgede inşa edilen kuleler, Olba Hanedanlığı döneminde küçük yönetim bölgelerini koruma gereğine işaret etmektedir. ${ }^{42}$

Sonuç olarak yapıların taşıdığı belirgin mimari özellikler, bölgede yüzyıllardır süren mimari karakteristiğin Bizans devrinde Ermeni vasallar tarafından sürdürüldügüüü göstermektedir. Bölgede salt veya tipik Ermeni dönemi mimari özelliklerine bağlanamayacak, bölgesel ve dönemsel anlamda yaygın bir mimari geleneğin bulunduğu

41 Serra Durugönül, "Dağlık Kilikia Bölgesinde (Mersin ve İlçelerinde) Kent, Mimari ve Malzeme," Tarih İçinde Mersin Kollokium'u, (Mersin: Mersin Üniversitesi, 2005), 2: 29.

42 Serra Durugönül, "1996 Yılı İçel İli (Antik Dağlık Kilikya) Yüzey Araştırması ile Kuleler-Kaleler ile Yerleşimlere Olan İlişkileri,” 15. Araştırma Sonuçları Toplantısı, (Ankara: Kültür Bakanlığı Yayını, 1998), 1: 284; ayrıntılı bilgi için bkz. Serra Durugönül, Türme und Siedlungen im Rauhen Kilikien: Eine Untersuchung zu den Archaologischen Hinterlassesschaften im Olbischen Territorium (Bonn: Dr.R Habelt GMBH, 1998). 
açıktır. Dağlık Kilikya bölgesinde, Silifke Kalesi, Kız Kalesi (Korykos), Gözne Kalesi; Ovalık Kilikya’da ise Y1lan Kale, Tumlu Kalesi, Kozan Kalesi Anavarza Kalesi ve Bağras Kalesi'nde bölgesel ortak özellikler yaygın olarak görülmektedir. Bu özellikler, kalelerin ana kaya üzerine inşa edilmiş olmaları, burç ve kulelerin çoğunlukla dairesel biçimli olması, ana ve ara yollar üzerinde stratejik noktalara konumlanması, bosajlı taş örgü kullanılması, şapel ve kiliselerin yer alması, Ortaçağ’’n tarihsel ve kültürel etkilerini taşıması olarak özetlenebilir. Bu bölgedeki ve Anadolu'nun farklı coğrafyalarında görülen kalelerdeki genel özellikleri sadece Ermeni mimari özellikleri olarak ifade etmenin doğru olmayacağı öne sürülebilir. Ayrıca her kale, içinde bulunduğu topografyaya uygun inşa edildiğinden kendi mimari özellikleri kapsamında değerlendirilmelidir. Kilikya bölgesi Ortaçağ savunma yapılarının, gözetleme kulelerinin ve kale yapılarının bölgeye özgü bir mimari gelenek ve düzen içinde inşa edildiği anlaşılmaktadır.

\footnotetext{
Hakem Değerlendirmesi: Dış bağımsız.

Çıkar Çatışması: Yazarlar çıkar çatışması bildirmemiştir.

Finansal Destek: Yazarlar bu çalışma için finansal destek almadığını beyan etmiştir.

Peer-review: Externally peer-reviewed.

Conflict of Interest: The authors have no conflict of interest to declare.

Grant Support: The authors declared that this study has received no financial support.
}

\section{Kaynakça/References}

Armenian Highland. “Goshavank.” Erişim 08.05.2019. www.armenianhighland.com/churches/ chronicle450.html

Armenian Highland. "St. Gregory Church.” Erişim 08.05.2019. www.armenianhighland.com/churches/chronicle450.html

Aydın, Ayşe. “Kilikya ve Isauria Bölgesi Vaftiz Yapıları.” Sanat Tarihi Dergisi 15 (2006): 1-19.

Dedeyan, Gérard. La Chronique Attribuée au Connétable Smbat. Paris: L'Académie des Inscriptions et Belles-Lettres, 1980.

Durugönül, Serra. "Dağlık Kilikia Bölgesinde (Mersin ve İlçelerinde) Kent, Mimari ve Malzeme." Tarih İçinde Mersin Kollokium'u. Mersin: Mersin Üniversitesi, 2005. 2: 28-33.

Durugönül, Serra. "1996 Yılı İçel İli (Antik Dağlık Kilikya) Yüzey Araştırması ile Kuleler-Kaleler ile Yerleşimlere Olan İlişkileri.” 15. Araştırma Sonuçları Toplantısı. Ankara: Kültür Bakanlığı Yayın1, 1998. 1: 281-293.

Durugönül, Serra. Türme und Siedlungen im Rauhen Kilikien: Eine Untersuchung zu den Archaologischen Hinterlassesschaften im Olbischen Territorium. Bonn: Dr. R Habelt GMBH, 1998.

Durukan, Murat. Mersin'den Tarsus'a Kilikia Kiyllarındaki Kayıp Kentler (Zephyrion, Ingira, Aulai, Ankhiale, Kynda-Kundi, Sizzu). İstanbul: Arkeoloji ve Sanat Yayınları, 2015.

Edwards, Robert W. "The Role of Military Architecture in Medieval Cilicia: The Triumph of a Non-Urban Strategy.” Armenian Cilicia. Ed. R. Hovannasian ve S. Payaslian. California: Mazda, 2008, 153-183. 
Edwards, Robert W. The Fortifications of Armenian Cilicia. Washington: Dumbarton Oaks, 1987.

Edwards, Robert W. "Ecclesiastical Architecture in the Fortifications of Armenian Cilicia." Dumbarton Oaks Papers, 36 (1982): 155-176. Erişim 07.08.2018. https://www.jstor.org/stable/1291466.

Frazee, Charles A. "The Christian Church in Cilician Armenia: Its Relations with Rome and Constantinople to 1198." Church History 45/ 2 (1976): 166-184.

Gough, Michael. "The Emperor Zeno and Some Cilician Churches.” Anatolian Studies 22 (1972): 199-212.

Gottwald, J. "Die Kirche und das Schloss Paperon in Kilikisch-Armenien." Byzantinische Zeitscrift 1 (1936): 86-100.

Herzfeld E. ve S. Guyeu. Meriamlik und Korykos, zwei christliche Ruinenstatten des rauhen Kilikiens. Manchester: Manchester University Press, 1930.

Hild, Friedrich ve Hansgerd Hellenkemper. Kilikien Isaurien. Wien: Verlag der Österreichhischen Akademie der Wissenschaften, 1990.

Hill, Stephen. The Early Byzantine Churches of Cilicia and Isauria. Ed. A. Breyer ve J. Haldon. Hampshire: Variorum, 1996.

İşler, Bülent. "Gürcü ve Bizans Kiliselerinde Onbirinci ve Onüçüncü Yüzyıllara Tarihlendirilen Ek Mekânlar.” Onikinci ve Onüçüncü Yüzyıllarda Bizans Dünyasında Değişim, I. Uluslararası Sevgi Gönül Sempozyumu 25-28 Haziran 2007 Bildiriler. Ed. A. Ödekan, E. Akyürek ve N. Necipoğlu. İstanbul: Vehbi Koç Vakfi, 2010, 400-407.

Kadiroğlu, Mine ve Bülent İşler. Gürcü Sanatının Ortaçă̆̆. Ankara: Bilgin Kültür Sanat, 2010.

Kaşgarlı Aktok, Mehlika. Kilikya Tâbi Ermeni Baronluğu Tarihi. Ankara: Kök, 1990.

Mango, Cyrill. "Isaurian Builders.” Polychronion. Ed. P. Wirt. Heidelberg: Festschrift F. Dolger, 1966, 358-365.

Mersin Kültür Turizm. “Kaleler, Hisarlar ve Tabyalar.” Erişim 17 Mayıs 2019 www.mersinkulturturizm.gov.tr/TR-73469/kaleler--hisarlar-vetabyalar.html.

Mersin: Örenyerleri, Kaleleri, Müzeleri. Haz. Filiz Kerem. 2. Bask1, İstanbul: Ekin, 2009.

Molin, Kristian. Unknown Crusader Castles. New York: Hambledon Continuum, 2001.

Robinson, F.C.R. ve P.C. Hughes. "Lampron: Castle of Armenian Cilicia.” Anatolian Studies 19 (1969): 183-207.

“Samtavro Katedrali." Erişim 24.12.2019. http://www.dzeglebi.ge/dzeglebi/s/samtavro.html

Strabon. Antik Anadolu Coğrafyası: Geographika. Çev. A. Pekak. İstanbul: Arkeoloji ve Sanat Yayınları, 2005.

Youngs, G. R. “Three Cilician Castles.” Anatolian Studies 15 (1965): 113-134. 
